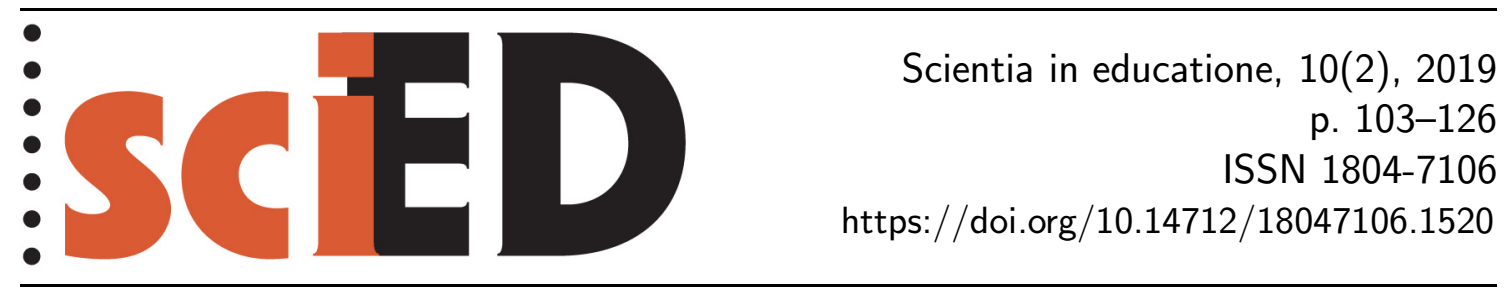

\title{
Vliv procvičování na Khan Academy na znalosti a dovednosti žáků $\mathrm{v}$ matematice
}

\author{
Jiř́ Vančura
}

\begin{abstract}
Abstrakt
Ve dvou předkládaných kvantitativních studiích jsme zkoumali vliv procvičování učiva matematiky pomocí interaktivní sbírky úloh Khan Academy na znalosti a dovednosti žáků čtyřletého gymnázia. V první studii z roku 2016/2017 jsme se zaměřili na přenos naučených procedurálních znalostí a dovedností z anglického prostředí Khan Academy do českého školního kontextu. Ve druhé studii z roku 2017/2018 jsme se věnovali otázce rozvoje konceptuálních znalostí skrze procvičování procedurálních dovedností. Obě studie probíhaly na stejném vzorku 44 žáků ze dvou tříd pražského gymnázia. Data jsme analyzovali pomocí testování hypotéz s hladinou spolehlivosti $5 \%$. Autor studií byl v době výzkumu učitelem matematiky těchto žáků. Zatímco v první studii byl přínos procvičování statisticky významný, ve druhé studii nebyl rozvoj konceptuálních znalostí žáků tak jednoznačný. Sekundárně jsme se věnovali žákovskému vnímání vlivu Khan Academy na jejich znalosti a dovednosti.
\end{abstract}

Klíčová slova: online procvičování, Khan Academy, konceptuální znalost, procedurální znalost, Bloomova taxonomie.

\section{The Impact of Khan Academy Practice on the Knowledge and Skills of Pupils in Mathematics}

\begin{abstract}
The two presented quantitative studies examine the degree to which the online practice available from the Khan Academy helps improve the knowledge and skills of grammar school students. The first study, carried out in 2016/2017, focused on the transfer of procedural knowledge acquired via the Khan Academy online platform into the Czech classroom context. The second study, carried out in $2017 / 2018$, investigates the development of conceptual knowledge through online practice or procedural knowledge. Both studies worked with an identical sample of 44 students, namely two same grade classes of a grammar (high) school in Prague. Collected data were subjected to a hypothesis testing with a $5 \%$ significance level. At the time when the study was performed, the researcher was employed as the math teacher of the two respective classes. Whereas the first study arrived at statistically significant and strongly positive results, the second study did not indicate any significant development of the students' conceptual knowledge. Secondarily, we investigated the students' views on the benefits of online practice for their knowledge and skills.
\end{abstract}

Key words: online practice, Khan Academy, conceptual knowledge, procedural knowledge, Bloom's taxonomy. 
Tvrzení, že dobré porozumění matematickým konceptům podporuje procedurální dovednosti, je odborníky dlouhodobě akceptováno. Otázkou zůstává, zda i naopak osvojení procedurálních dovedností podporuje konceptuální znalost (Allock et al., 2016). V rešeršním článku (Rittle-Johnson et al., 2015) dospívají autoři k názoru, že platí i opačný vztah, kdy dostatečné zvládnutí procedur a postupů řešení úloh přispívá k lepšímu porozumění konceptům. Ke stejnému názoru se přiklání i kniha (Rittle-Johnson \& Schneider, 2016), nicméně empirických podkladů pro tento závěr není mnoho. Proto jsme se na tuto otázku také zaměřili.

Vhodným a velmi populárním nástrojem k získávání procedurálních dovedností je Khan Academy (dále jen KA) a její interaktivní sbírka matematických úloh. Navíc zavádění digitálních technologií do výuky matematiky je trendem posledních let. Přes velkou popularitu KA chybí empirické výzkumy o jejím vlivu na znalosti a dovednosti žáků. Cílem našich studií bylo prověřit jednak přínos procvičování na Khan Academy v oblasti procedurálních znalostí žáků, na které KA prvoplánově cílí, a následně zjistit, zdali procedurální zvládnutí úloh podporuje i konceptuální znalosti. Sekundárně jsme se zaměřili na žákovské vnímání přínosů KA pro jejich znalosti a dovednosti.

KA je koncipována spíše k samostudiu, proto ji v našich studiích využíváme k domácímu procvičování, které je ve vhodné formě dle výzkumů přínosem především při výuce matematiky na střední škole, viz kapitola 1.3. Interaktivní sbírka na KA je z hlediska domácího procvičování v souladu s výzkumy a představuje tak ideální nástroj k odpovědi na naše výzkumné otázky.

Vzhledem k omezenému vzorku 44 žáků v naší studii jsme zvolili netradiční design, kdy jsme opakovaně pretestovali a posttestovali žáky v symetrickém vzorci. Z organizačních důvodi̊ také nebylo možné vyčlenit kontrolní skupinu, proto každý žák byl vždy bud' pretestován nebo posttestován. Takto jsme získali dostatečné množství relevantních dat, které jsme následně podrobili testování hypotéz s hladinou spolehlivosti $5 \%$.

V souladu s rozsáhlou implementační studií z USA (Murphy et al., 2014) a s naší předchozí studií (Vančura, 2016) se žáci na KA neučili nové dovednosti, ale procvičovali řešení již probraných typů úloh.

\section{TEORETICKÝ RÁMEC}

\subsection{PROCEDURÁLNí A KONCEPTUÁLNí ZNALOST}

Mezi odbornou veřejností panuje jednoznačnější shoda na pojmu procedurální znalosti, který označuje schopnost provádět dané procedury či postupy k řešení známých problémů (Rittle-Johnson \& Schneider, 2016). Procedurální znalost obsahuje nejen znalost matematických objektů a způsobů manipulace s nimi, ale také znalost způsobu zápisu a reprezentace těchto objektů (Haapasalo \& Kadijevich, 2000). Definice pojmu konceptuální znalosti není v odborné veřejnosti ustálená, obecně se jedná o znalost faktů, principů a konceptů, které jsou spíše abstraktní (Rittle-Johnson \& Schneider, 2016). Procedurální znalost obvykle vyžaduje prosté, bezmyšlenkovité použití naučeného postupu, zatímco konceptuální znalost většinou vyžaduje vědomé rozmýšlení postupu (Haapasalo \& Kadijevich, 2000). Pro účely kvantitativní, empirické studie jsou stěžejní metody ověřování, které nám také lépe ilustrují rozdíly mezi oběma skupinami znalostí.

Stejně jako samotná definice jsou i metody ověřování procedurálních znalostí jasněji vymezené. Testové úlohy téměř vždy vyžadují řešení typově známého problému 
s využitím známé procedury. Měřena je pak zpravidla správnost a přesnost výsledků či procedur (Rittle-Johnson \& Schneider, 2016). Občas výzkumníci do procedurální znalosti zahrnují i schopnost použít známou proceduru v neznámém kontextu nebo schopnost ji mírně upravit pro účely nového problému (Rittle-Johnson, 2006; Renkl et al., 1998). Jako př́klad ověřující procedurální znalost uvádí Haapasalo a Kadijevich (2000) úlohu, kde je zadaná vzdálenost mezi dvěma městy, ze kterých vyráží proti sobě dvě auta různou, zadanou rychlostí, a úkolem žáka je určit, za jak dlouho se auta setkají. Haapasalo a Kadijevich dále doplňují, že i procedurální znalost může vyžadovat vědomé přemýšlení, kdy žák například zkombinuje dva postupy k řešení daného problému.

Metody ověřování konceptuálních znalostí jsou, stejně jako definice, pestřejší a zahrnují mnoho různých typů úloh. Testové úlohy by měly být pro žáky nové, aby žák musel řešení odvodit z převážně abstraktních, konceptuálních znalostí (Rittle-Johnson \& Schneider, 2016). Obecně zde najdeme úlohy vyžadující vysvětlování, ilustrování na prŕkladech, rozřazování do kategorií, vytváření definic nebo hypotéz apod. Konceptuální znalost je ověřována např́íklad úlohami, kde má žák zhodnotit správnost předloženého řešení (Dixon et al., 2001; Star \& Rottle-Johnoson, 2009), uspořádat př́klady do daných kategorií (Lavigne, 2005), vybrat nebo vytvořit definici daného konceptu (Knuth et al., 2006) či vysvětlit, proč daný postup funguje (Berthold \& Renkl, 2009). Na druhou stranu ani úlohy ověřující konceptuální znalost nemusí být otevřené, Kadijevich a Marinkovic (2006) uvádí následující př́íklad testující konceptuální znalost: „Dvě fixy stojí více než tužky, stojí pět fixů více než sedm tužek?"“

Kvůli nejednoznačnosti definice konceptuálních znalostí jsme se rozhodli pro ověřování použít Bloomovu taxonomii, která je naopak dobře ukotvená a stále hojně využívaná $\mathrm{k}$ ověřování znalostí žáků. V Bloomově taxonomii najdeme úlohy ověřující procedurální znalosti v matematice téměř výhradně ve skupině 3 (Aplikovat) dimenze kognitivního procesu, zatímco úlohy oveřuuící konceptuální znalosti v matematice najdeme převážně v ostatních skupinách mimo skupiny 1 (Zapamatovat), viz následující kapitola 1.2. Z Bloomovy taxonomie jsme vybrali ty kategorie, které dle všech výše uvedených vymezení spadají výhradně do skupiny procedurálních (3.a provádět naučený postup v typově známé úloze), respektive konceptuálních znalostí (2.b - ilustrovat daný koncept na vhodném př́kladu, 5.a - kontrolovat správnost předloženého postupu řešení), viz dále.

Z výzkumů je zřejmé, že konceptuální a procedurální znalosti spolu souvisí (Rittle-Johnson \& Schneider, 2016) a existuje řada studií, které ukazují, že rozvoj konceptuálních znalostí zlepšuje i znalosti procedurální. Evidence pro opačný vztah již není tak silná (Rittle-Johnson et al., 2015), existují studie, dle kterých rozvoj procedurálních znalostí zlepšuje i konceptuální znalosti, tak studie, které nezjistili významné zlepšení konceptuálních znalostí (Kamii \& Dominick, 1997). Proto se v našich studiích zaměřujeme i na tuto otázku.

\subsection{Revidovaná Bloomova taxonomie}

Původní Bloomova taxonomie, definovaná v roce 1956 (Bloom, 1956), rozlišovala 6 úrovní kognitivních dovedností. Úrovně byly navíc hierarchické, kdy dosažení dané úrovně vyžadovalo zvládnutí všech nižších úrovní. O půl století později vznikla revidovaná Bloomova taxonomie (Anderson \& Krathwohl, 2001), dále jen RBT, která jednak mírně upravila a podrobněji rozpracovala dimenzi kognitivních dovedností (procesů), zrušila jejich hierarchii s výjimkou úrovně 1 a zavedla druhou, znalostní 
dimenzi. Výhodou RBT oproti obecné teorii konceptuálních a procedurálních znalostí je jasnější klasifikace vzdělávacích cílů a především jednoznačný seznam typů úloh určených $\mathrm{k}$ ověřování jednotlivých vzdělávacích cílů.

V RBT reprezentované tab. 1 označuje každá buňka tabulky jednu kategorii vzdělávacích cílů, které mají po revizi dvě dimenze. Vodorovná dimenze odpovídá původní Bloomově taxonomii a nazývá se Dimenze kognitivního procesu. V této dimenzi najdeme šest hlavních úrovní, které se dále dělí na užší podúrovně. Naše studie pracují s úrovněmi 2,3 a 5 , proto uvedeme i jejich podúrovně. Úroveň 2 (rozumět) se dále dělí na dovednosti: 2.a - interpretovat, 2.b - ilustrovat na př́kladech, 2.c - klasifikovat, 2.d - sumarizovat, 2.e - vyvozovat, 2.f - porovnávat, 2.g vysvětlovat. Úroveň 3 (Aplikovat) se dále dělí na podúrovně: 3.a - provádět, 3.b implementovat. Úroveň 5 (Hodnotit) se dále dělí na podúrovně: 5.a - kontrolovat, 5.b - posuzovat. Dle RBT se již nejedná o taxonomii v pravém slova smyslu, tedy žák může dosáhnout vyšších úrovní, aniž by si osvojil úrovně nižší s výjimkou úrovně 1 , která je nutným předpokladem pro všechny další úrovně. Žáci mohou například aplikovat, aby zlepšili svou schopnost rozumět (Anderson, 2005). Vyššími kognitivními dovednostmi nebo procesy označujeme dovednosti od úrovně 2 výš.

Tab. 1: Revidovaná Bloomova taxonomie s naznačenou výzkumnou otázkou ii)

\begin{tabular}{|c|c|c|c|c|c|c|}
\hline $\begin{array}{l}\begin{array}{r}\text { Dimenze } \\
\text { kognitivního } \\
\text { procesu }\end{array} \\
\text { Znalostní } \\
\text { dimenze }\end{array}$ & 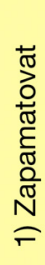 & 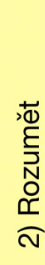 & 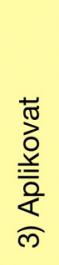 & 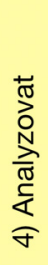 & 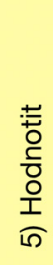 & 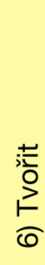 \\
\hline I) Znalost faktů & & & & & & \\
\hline $\begin{array}{l}\text { II) Konceptuální } \\
\text { znalost }\end{array}$ & & & & & & \\
\hline $\begin{array}{l}\text { III) Procedurální } \\
\text { znalost }\end{array}$ & & & & & & \\
\hline $\begin{array}{l}\text { IV) Metakognitivní } \\
\text { znalost }\end{array}$ & & & & & & \\
\hline
\end{tabular}

Znalostní dimenze byla přidána s cílem sjednotit Bloomovu taxonomii napřrič předměty, kdy původní taxonomie byla vždy upravována pro potřeby konkrétního předmětu či výukové oblasti (Anderson, 2005). Úrovně II a III této dimenze ne zcela odpovídají procedurální a konceptuální znalosti z předchozí kapitoly, zde se jedná o obsahové vymezení vzdělávacího cíle a tvoří jen jednu z jeho dvou složek. Znalost faktů zahrnuje především terminologii a základní pojmy nezbytné pro orientaci v předmětu. Konceptuální znalost dle RBT obsahuje klasifikaci a kategorie faktů, principy, teorie, modely a struktury a také souvislosti mezi nimi. Procedurální znalost dle RBT sestává z postupů, metod a algoritmů, které řeší daný typ problémů. Konečně metakognitivní znalost zahrnuje znalost svých vlastních schopností a limitů, znalost strategií a možností seberegulace, obecně znalost o kognici.

Vzdělávací cíl tak sestává ze dvou složek, např́iklad cíl: „Žák používá doplnění na čtverec k vyřešení kvadratické rovnice." spadá do úrovně 3 dimenze kognitivních procesů a úrovně III dimenze znalostí. Vzdělávací cíle nejsou rovnoměrně rozprostřeny např́ič celou tabulkou RBT a toto rozdělení se pro jednotlivé vzdělávací oblasti velmi liší. Např́klad v matematice se většina vyučování a často i výzkumu zaměřuje právě na buňku 3-III neboli aplikování procedurálních znalostí (Crompton et al., 2018). 
Procedurální znalost vymezenou v předchozí kapitole najdeme především ve zmíněné buňce 3-III a pro účely studie za procedurální znalost považujeme pouze znalosti v buňce 3.a-III, nebot buňku 3.b implementaci, která vyžaduje volbu a úpravu postupu pro řešení nové úlohy, by někteří autoři mohli řadit spíše ke konceptuální znalosti (Haapasalo \& Kadijevich, 2000; Star, 2005).

Konceptuální znalost $\mathrm{z}$ minulé kapitoly je rozprostřena převážně ve druhém řádku RBT, ale najdeme ji i v buňce 5-III, kam spadá např́klad hodnocení předloženého řešení úlohy. Ve studii se nezaměřujeme na všechny úrovně odpovídající konceptuálním znalostem, ale vybíráme jen dvě kategorie vzdělávacích cílů -2 .b-II (ilustruvat koncept na prŕkladech) a 5.a-III (kontrolovat správnost předloženého postupu řešení), jak ukazuje tab. 1. Tyto kategorie jsme zvolili, nebot vyhovují všem výše uvedeným vymezením pojmu konceptuální znalost, a protože je, na rozdíl od mnohých dalších, možné vytvářet mnoho testových úloh, které je ověřují téměř v každé oblasti středoškolské matematiky. Lze je tak spolehlivě a opakovaně testovat a navíc se dají dobře navázat na úlohy z KA. Testové úlohy zaměřené na kategorii 5.a-III předkládají postup řešení matematické úlohy a vyžadují od žáka ověření správnosti tohoto postupu. V návrhu testových úloh kategorie 5.a-III vycházíme z postupů, které žáci procvičovali, a vkládáme do nich chybné kroky. Testové úlohy kategorie 2.b-II pracují s koncepty, které žáci procvičovali, a vyžadují uvedení př́kladů podobných těm, se kterými již žáci pracovali, např. graf funkce rostoucí na intervalu $(-3 ; 3)$. Jiné, vyšší kognitivní dovednosti jsme netestovali, nebot jsme s ohledem na menší výzkumný vzorek nechtěli studii př́liš roztř́štit a omezit tak signifikantnost výsledků.

Konkrétní příklady úloh z procvičování a souvisejících testových úloh jsou uvedeny v kapitole 3.4 .

\subsection{DOMÁCÍ ÚKOLY A PROCVIČOVÁNí}

Domácí úkoly jsou běžnou složkou výuky matematiky na střední škole. Z řady studií vyplývá, že žáci úkolům věnují více úsilí, pokud je jejich práce pečlivě kontrolována (Strandberg, 2013). Pokud naopak učitel domácí úkoly nehodnotí a bez větší pozornosti je přechází, mají žáci pocit, že při plnění úkolu mrhají svým časem (Strandberg, 2013; Wilson \& Rhodes, 2010). Je přínosné, pokud jsou žáci přesvědčeni, že úkoly jsou smysluplné a že je jejich úsilí oceňováno (Bempechat et al., 2011). Žáci, kteří navštěvují školy s větším množstvím domácích úkoli̊, dosahují lepších výsledků. Tento vztah však neplatí univerzálně napříč předměty a ročníky. Nejsilnější je korelace právě u matematiky (Fan et al., 2017; Trautwein \& Lüdtke, 2009). Co se týče ročníku, nejsilnější korelace vychází v případě studentů středních škol, naopak u žáků prvního stupně je tato korelace téměř nulová (Fan et al., 2017). Žáci, kteří dosahují lepších výsledků, tráví plněním domácích úkolů méně času v rámci tř́idy (Dettmers et al., 2010). Poměrně známá studie (Mueller \& Dweck, 1998) ukázala, že pokud oceňujeme inteligenci žáků, můžeme tím snížit jejich motivaci, výkon i sebevědomí. Naopak, oceňujeme-li úsilí žáků, můžeme jejich motivaci i výkon zvýšit. Pokud dokážeme objektivně měřit úsilí, které žáci vynaložili při plnění domácích úkolů, dává nám to jako učiteli velmi účinný nástroj pro motivaci a hodnocení žáků.

Pár studií naznačuje, že prostředí, které žákům umožňuje cvičení opakovat, poskytuje okamžitou zpětnou vazbu a nápovědy, může vést $\mathrm{k}$ lepším výsledkům než prostředí, které žákům odhalí správnou odpověd’ bez možnosti opravy (Attali, 2015; Clarina \& Koul, 2003). Níže popsaná interaktivní cvičení z matematiky, která KA nabízí, jsou v souladu s výše uvedenými poznatky. 


\section{KHAN ACADEMY}

Podrobný popis prostředí KA a možnosti jeho využití ve výuce matematiky jsme podrobně popsali v článku (Vančura, 2018b). Zde se proto omezíme na stručný popis a vlastnosti KA související s popisovanými studiemi.

KA je nezisková organizace, která nabízí bezplatné online vzdělávací zdroje v anglickém jazyce. Na počátku, v roce 2008, platforma nabízela pouze matematická, výuková videa, která si ale získala mezi uživateli značnou oblibu, i kvůli nim patří mezi nejpoužívanější vzdělávací weby s více než 60 miliony návštěvníků měsíčně (Similar web, 2019). Dnes KA nabízí širokou paletu vzdělávacích zdrojů pokrývající většinu školské matematiky od základní školy po základy vysokoškolské matematiky, přírodní vědy, historii, informatiku a další oblasti. Mimo výukových videí nabízí také interaktivní sbírku úloh z matematiky, kterou využíváme v našich studiích a kterou popíšeme podrobněji. Přes velkou oblibu KA přetrvává nedostatek studií, které by empiricky zkoumaly vliv KA na znalosti a dovednosti žáků. Proto jsme se rozhodli provést studie právě s tímto zaměřením.

Sbírka je rozdělena do patnácti kapitol dle témat a dvanácti kapitol dle ročníku. Každé z celkem 1497 cvičení obsahuje řadu úloh zaměřených na jednu danou znalost. Cvičením tedy označujeme soubor úloh se stejným zaměřením.

$\mathrm{K}$ interaktivní sbírce úloh můžeme přistupovat bud' v roli žáka, nebo v roli učitele. Žákovi sbírka nabízí procvičování s okamžitou zpětnou vazbou. Žák si u každé úlohy může zobrazit vzorový postup řešení této úlohy nebo výukové video vysvětlující řešení analogického př́kladu. Ke splnění cvičení musí žák vyřešit alespoň $70 \%$ zadaných úloh napoprvé a bez zobrazení vzorového postupu. Níže ilustrujeme žákovské procvičování podrobně na konkrétním příkladu a dále popisujeme možnosti učitelského profilu, který nabízí podrobný přehled o procvičování a úspěšnosti žáků.

Podívejme se nyní podrobněji na konkrétní cvičení. Jako ilustrační př́klad použijeme cvičení Write standard equation of a circle (obr. 1). Úkolem žáka je zapsat středovou rovnici kružnice dané kružnice (obr. 1 - [4]). Rovnici je třeba napsat do textového pole [3], které je uzpůsobené k zadávání matematických vzorců. Odpo-

Obr. 1: Screenshot cvičení na Khan Academy

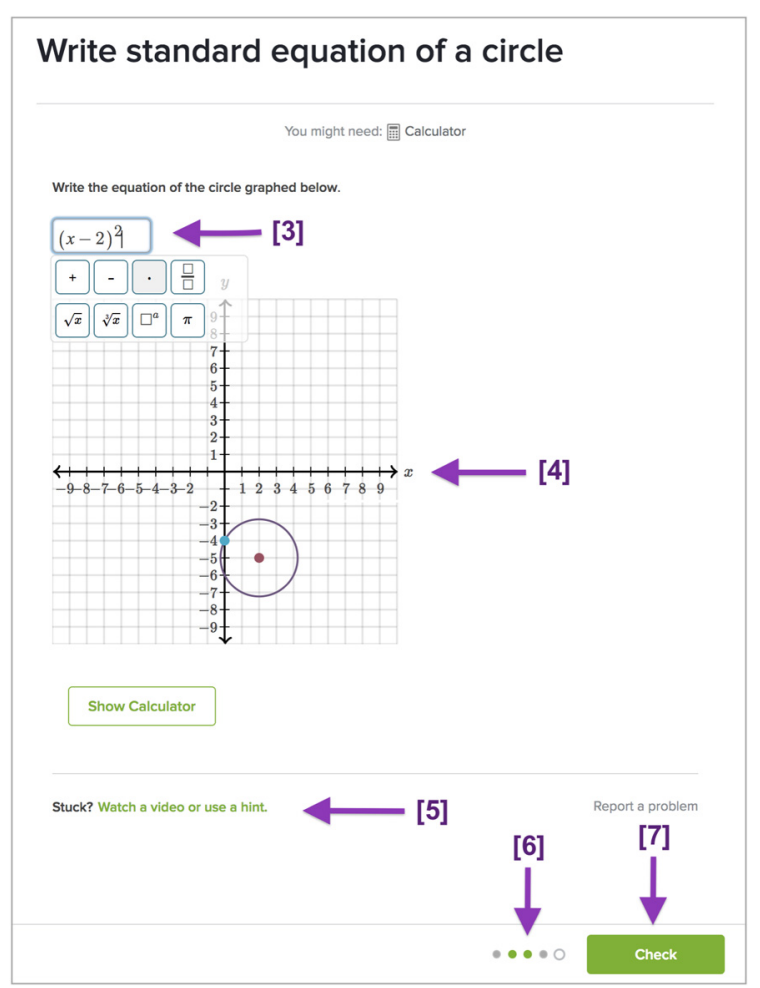


Obr. 2: Screenshot výukového videa na Khan Academy
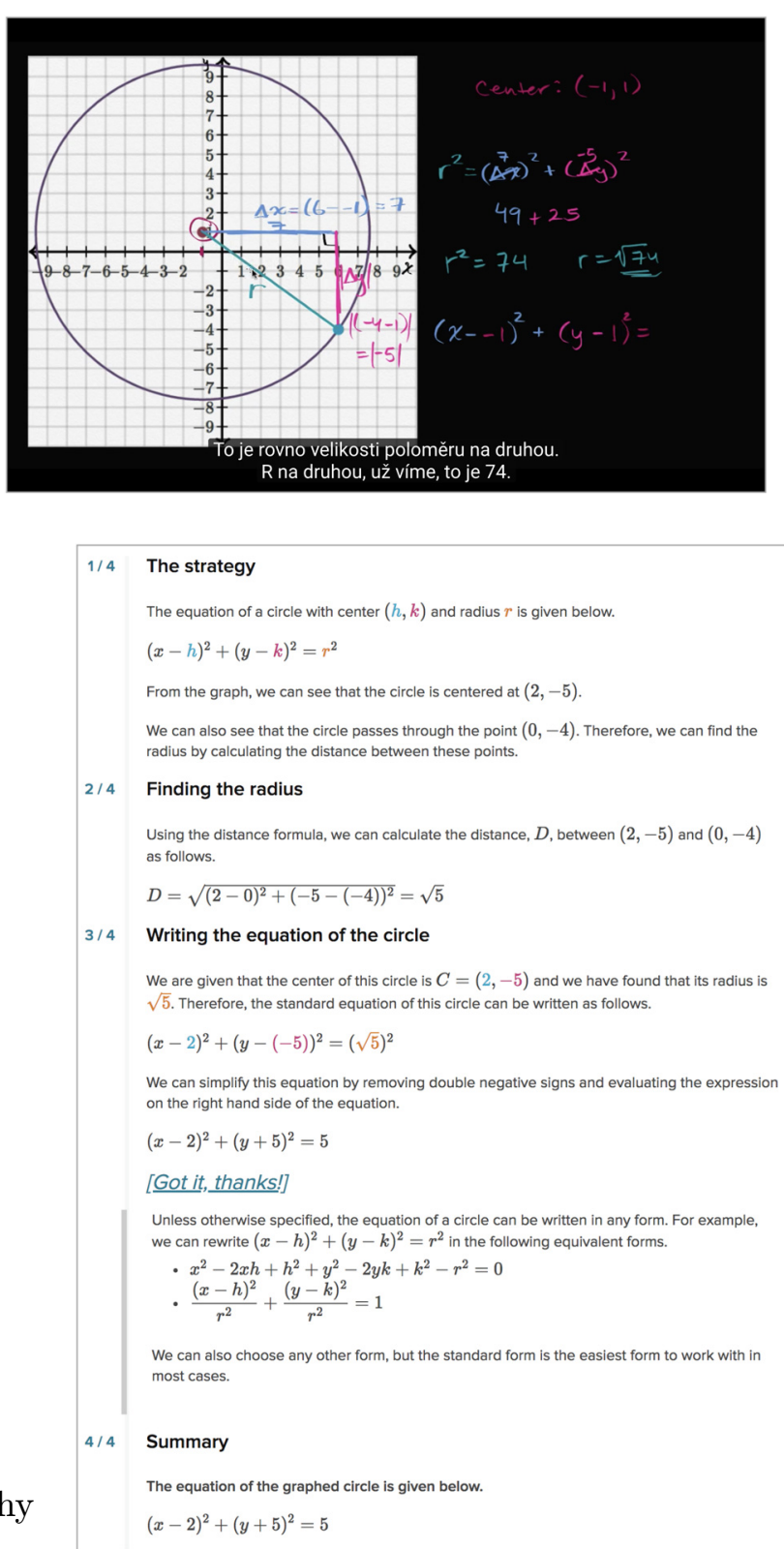

$(x-2)^{2}+(y+5)^{2}=5$
Obr. 3: Screenshot vzorového řešení úlohy z obr. 1

věd’ žák potvrdí stiskem tlačítka Check [7]. V př́ípadě, že žák odpoví chybně, musí chybu napravit a zapsat rovnici správně, poté může pokračovat $\mathrm{k}$ další úloze, ale tato úloha již nebude započítána jako splněná. Pokud žák nedokáže chybu opravit nebo si s řešením vůbec neví rady, má dvě možnosti nápovědy, které zobrazí kliknutím na odkaz [5]. První možností je výukové video, které podrobně popisuje řešení podobného př́kladu (obr. 2). Video je doprovázeno anglickým výkladem a některá videa nabízejí i české titulky. Druhou možností je zobrazení podrobného vzorového postupu řešení dané úlohy (obr. 3), v tom případě ale úloha nebude započítána jako splněná. Na konci vzorového postupu žák najde správnou odpověd’, přesto je třeba ji zadat do textového pole [3]. Tečky ve spodní části obrazovky [6] znázorňují žákovu úspěšnost. Úlohy, které vyřeší napoprvé a bez zobrazení vzorového postupu správně, jsou započítány jako splněné a znázorněny zelenou tečkou, ostatní úlohy jsou pak znázorněny šedou tečkou. Po dokončení všech úloh ve cvičení se žákovi zobrazí shrnutí, které mimo jiné ukazuje jeho procentuální úspěšnost. Cvičení je započítáno jako splněné, pokud žák správně, napoprvé a bez nápovědy vyřešil alespoň $70 \%$ úloh, v opačném př́padě musí cvičení opakovat s jinými úlohami. Počet úloh ve cvičení se pohybuje zpravidla mezi čtyřmi a sedmi. 
Nyní přejdeme k učitelskému př́istupu ke sbírce úloh. Podrobně je využití učitelského účtu popsáno v článku (Vančura, 2018b). Učitel může jednotlivým žákům zadávat libovolná cvičení se zvoleným termínem splnění. Následně má učitel velmi podrobný přehled o činnosti jeho žáků na KA. U každé úlohy, kterou žák řešil, vidí učitel jeho odpověd', př́ipadně odpovědi, pokud žák neodpověděl napoprvé správně a odpověd’ opravoval. Dále si může učitel zobrazit souhrnnou tabulku, kde vidí procentuální úspěšnost jednotlivých žáků v jednotlivých cvičeních (obr. 4), tabulka zobrazuje vždy nejlepší dosažený výsledek. V naší studii jsme tak mohli snadno identifikovat žáky, kteří splnili domácí procvičování.

\begin{tabular}{|c|c|c|c|c|c|c|c|c|}
\hline STUDENTS & $\begin{array}{l}8 \\
\text { Power rule (with } \\
\text { rewriting the } \\
\text { expression) } \\
\text { Feb } 6\end{array}$ & $\begin{array}{c}\Delta \\
\text { Differentiate } \\
\text { integer powers } \\
\text { Imixed dositive } \\
\text { Feb 6 }\end{array}$ & $\begin{array}{l}\theta \\
\text { Derivatives of } \\
\text { sin }(x) \text { and } \cos (x) \\
\text { Feb } 6\end{array}$ & $\begin{array}{l}8 \\
\text { Basic derivative } \\
\text { rules: find the } \\
\text { error } \\
\text { Jan } 30\end{array}$ & $\begin{array}{c}\Delta \\
\text { Basic derivative } \\
\text { rules: table } \\
\text { Jan } 30\end{array}$ & $\begin{array}{c}\text { Power rule } \\
\text { (positive integer } \\
\text { Dowers) } \\
\text { Jan } 30\end{array}$ & $\begin{array}{c}8 \\
\begin{array}{c}\text { Differentiate } \\
\text { polynomials } \\
\operatorname{Jan} 30\end{array}\end{array}$ & $\begin{array}{c}\otimes \\
\text { Secant lines \& } \\
\text { average rate of } \\
\text { change } \\
\text { Jan } 23\end{array}$ \\
\hline 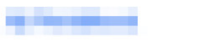 & 75 & 100 & 75 & 75 & - & 75 & 50 & - \\
\hline en & - & - & - & 100 & 100 & 100 & 25 & 100 \\
\hline Heth & - & - & - & 100 & - & 100 & 50 & - \\
\hline itan $=$ & 100 & 100 & 100 & 100 & 100 & 100 & 100 & - \\
\hline man & 100 & 100 & 100 & 100 & 100 & 100 & 100 & 100 \\
\hline nintin & 100 & 75 & 100 & 100 & 100 & 100 & 100 & 100 \\
\hline 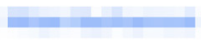 & 75 & 25 & 100 & 100 & 100 & 100 & 75 & 100 \\
\hline town ins & 75 & 75 & 50 & 75 & 100 & 100 & 100 & 75 \\
\hline 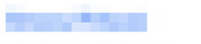 & 100 & 100 & 100 & 100 & 100 & 100 & 100 & 100 \\
\hline ning & 100 & 100 & 100 & 100 & 100 & 100 & 100 & 100 \\
\hline $2-1=$ & 75 & 75 & 75 & 75 & & 10 & $\overparen{1 \mathrm{nn}}$ & 75 \\
\hline
\end{tabular}

Obr. 4: Tabulka úspěšnosti žáků v jednotlivých cvičeních

\section{Metodika}

V rámci našich dvou studií jsme se zaměřili na následující výzkumné otázky.

\subsection{VÝZKUMNÉ OTÁZKY}

i) Umí žáci procedurální znalosti v oblasti analytické geometrie a komplexních čísel získané při procvičování na Khan Academy použít v českém školním kontextu?

ii) Rozvíjí procvičování na Khan Academy konceptuální znalosti, konkrétně vyšší kognitivní dovednosti 2.b-II - ilustrovat koncept na vhodných př́kladech a 5.a-III - kontrolovat správnost předloženého postupu dle RBT v oblasti diferenciálního a integrálního počtu (tab. 1)?

iii) Jak přínosné je procvičování na Khan Academy dle vnímání žáků z hlediska jejich znalostí?

K zodpovězení otázek jsme provedli dvě kvantitativní studie ve školních letech 2016/2017 a 2017/2018. První studie se zaměřila na výzkumnou otázku i), druhá na otázku ii). Otázce iii) se sekundárně věnovaly obě studie. Obě studie měly také obdobnou metodiku, proto je budeme popisovat společně. 
V průběhu obou studií byla vždy látka probrána v hodině, poté byla jedna polovina žáků ve škole pretestována na danou znalost. Dále za domácí úkol všichni žáci procvičovali zadané úlohy na KA a poté byla ve škole druhá polovina žáků posttestována. Rozdělení žáků do pretestovaných a posttestovaných skupin se každý týden měnilo v symetrickém vzorci, podrobně je tento postup popsán v kapitole 3.3.

První studie z roku 2016/2017 rozlišovala dva různé kontexty testování - kontext Khan Academy, kdy žáci řešili jednu úlohu ve formě screenshotu úlohy z KA, a český kontext, kdy žáci řešili jednu do češtiny přeloženou úlohu z KA bez grafických prvků KA jako jsou tlačítka, menu apod. Druhá studie z roku 2017/2018 nerozlišovala různé kontexty, žáci vždy řešili jednu českou úlohu zaměřenou bud’ na kategorii 2.b-II (ilustrovat př́kladech) nebo 5.a-III (kontrolovat) RBT. Podrobně je návrh testových úloh popsán v kapitole 3.4.

\subsection{VÝZKUMNÝ VZOREK}

Studie probíhaly ve školních letech 2016/2017 a 2017/2018 na Gymnáziu Přípotoční v Praze. Učastníky studií byli stejní žáci dvou paralelních tříd, říkejme jim A, B. Obě tř́idy pracovali v hodinách matematiky stejně, studie nepracovaly s experimentální a kontrolní skupinou. V roce 2016/2017 se jednalo o třetí ročníky střední školy, v následujícím roce o maturitní ročníky. Celkem se studií zúčastnilo $n=44$ žáků ve věku od 17 do 19 let. Rodným jazykem žáků je čeština, proto jedním z faktorů, který by mohl omezovat přínos procvičování na KA, je jazyková bariéra. Dodejme, že všichni žáci se ve škole učili anglický jazyk nejméně 9 let před začátkem studie. Většina z nich v době studie zvládala angličtinu na úrovni B2 nebo lépe, což dokládali certifikáty B2 First nebo C1 Advanced dle Cambridge Assessment (2019). Ve vzorku nebyl žádný žák se speciálními vzdělávacími potřebami (§16 zákona č. 561/2004 Sb.). Na čtyřletém Gymnáziu Př́potoční měli žáci v průběhu celého studia 4 povinné hodiny matematiky týdně a od druhého ročníku měla polovina každé třídy jednu hodinu týdně matematiky navíc, kde se probírala témata nad rámec povinných hodin. Žáci byli dobře obeznámeni s prostředím interaktivních cvičení na KA, neboẗ s nimi pracovali pravidelně od roku 2015, kdy probíhaly naše první studie ohledně postojů žáků ke KA a jejich jazykové bariéry (Vančura, 2017). Autor článku byl v době studie zároveň učitelem matematiky v obou tř́dách.

\subsection{SBĚR DAT}

Těžištěm výzkumných dat obou studií jsou výsledky žáki̊ v testech před a po procvičení na KA. S pouhými 44 žáky ve studii by jedno kolo pretestů a posttestů nepřineslo dostatečně robustní data, proto jsme zvolili vícekolový rozvrh testování. Další překážkou byla nemožnost vyčlenit kontrolní skupinu, proto se každý žák účastnil vždy jen pretestu nebo jen posttestu v každém kole.

Žáci každé třídy (A, B) byli rozděleni do čtyř skupin (A1, A2, A3, A4, B1, B2, B3, B4). Záměrem bylo vytvořit skupiny se srovnatelnými matematickými znalostmi, jedinou dostupnou metrikou byly známky žáků. Vytvořili jsme proto skupiny, mezi kterými byly co nejmenší rozdíly v průměru známek žáků z matematiky na vysvědčeních z 2. ročníku gymnázia. Vznikly tak skupiny, ve kterých se průměr známek na vysvědčení pohyboval mezi 2,9 a 3,3 . V každé skupině bylo pět až šest žáků.

Druhá studie z roku 2017/2018 měla oproti první studii z roku 2016/2017 jednodušší schéma (viz obr. 5), proto jím začneme. Látka byla nejprve probrána ve škole, následně měli žáci za domácí úkol každý týden splnit tři až čtyři zadaná cvičení, tj. soubory úloh na KA. Čtyři z osmi skupin byly vždy testovány před procvičením 


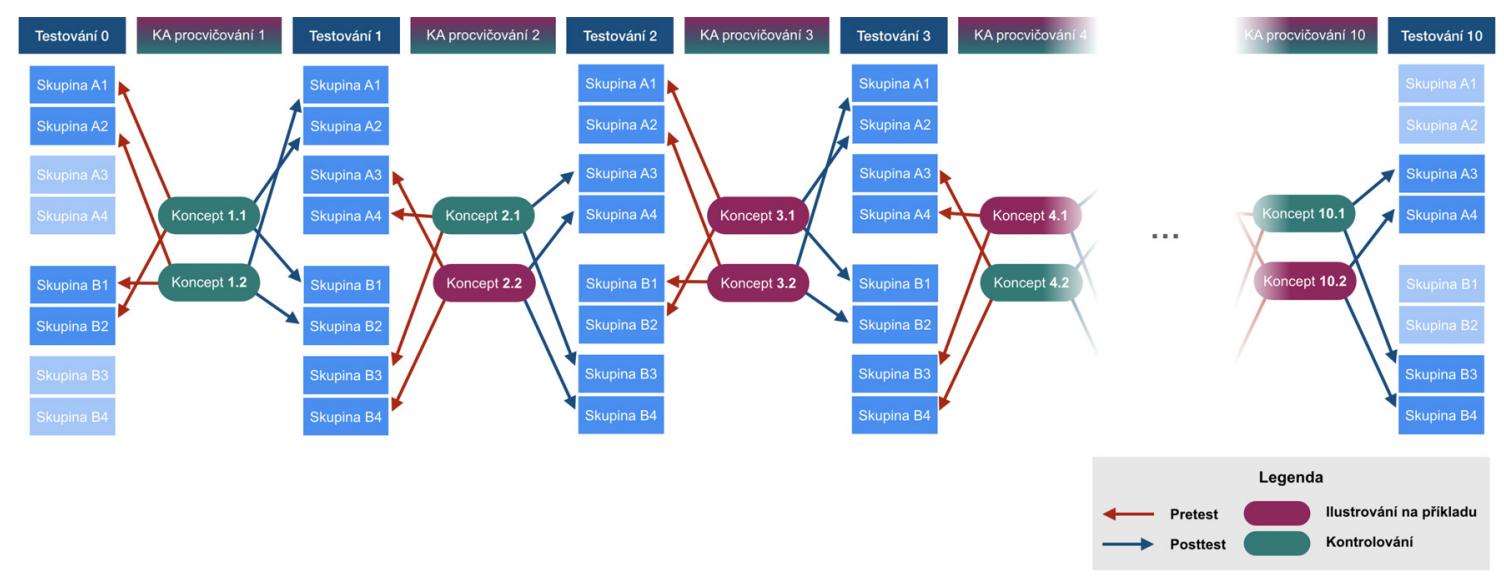

Obr. 5: Rozvrh testování žáků ve studii ve školním roce 2017/2018

a čtyři skupiny po domácím procvičení na KA. Připomeňme, že žáci nebyli rozděleni na kontrolní a experimentální skupinu, všichni procvičovali stejné matematické znalosti na KA. Pretestové a posttestové úlohy byly kvůli srovnatelnosti totožné a každá skupina byla v daném týdnu vždy jen pretestována nebo posttestována. Polovina testů byla zaměřena na kategorii 2.b-II (ilustrovat na příkladech) a druhá polovina testů byla zaměřena na kategorii 5.a-III (kontrolovat). Role skupin i kategorie testů byla v pravidelném vzoru obměňována tak, že z celkového počtu deseti kol testování byla každá skupina pětkrát pretestována a pětkrát posttestována a také 4-6krát testována na kategorii 2.b-II a 4-6krát testována na kategorii 5.a-III.

Např́klad při testování 2 (obr. 5) byly skupiny A1 a B2 testovány na dovednost ilustrovat na př́kladech konkrétní koncept 3.1 (interní označení) před procvičením na KA; skupiny A2 a B1 byly také pretestovány v kategorii 2.b-II, ale pro koncept 3.2 (interní označení); skupiny A3 a B3 byly testovány na dovednost kontrolovat předložený postup úlohy typu 2.1 (interní označení) po procvičení na KA a skupiny A4 a B4 byly také posttestovány, ale v kategorii 2.b-II pro koncept 2.2 (interní označení).

Předchozí studie ve školním roce 2016/2017 měla podobný průběh, ale byla složitější, nebot jsme u každé znalosti rozlišovali dva různé kontexty (kontext Khan Academy a český kontext). Průběh testování zachycuje obr. 6. Na druhou stranu

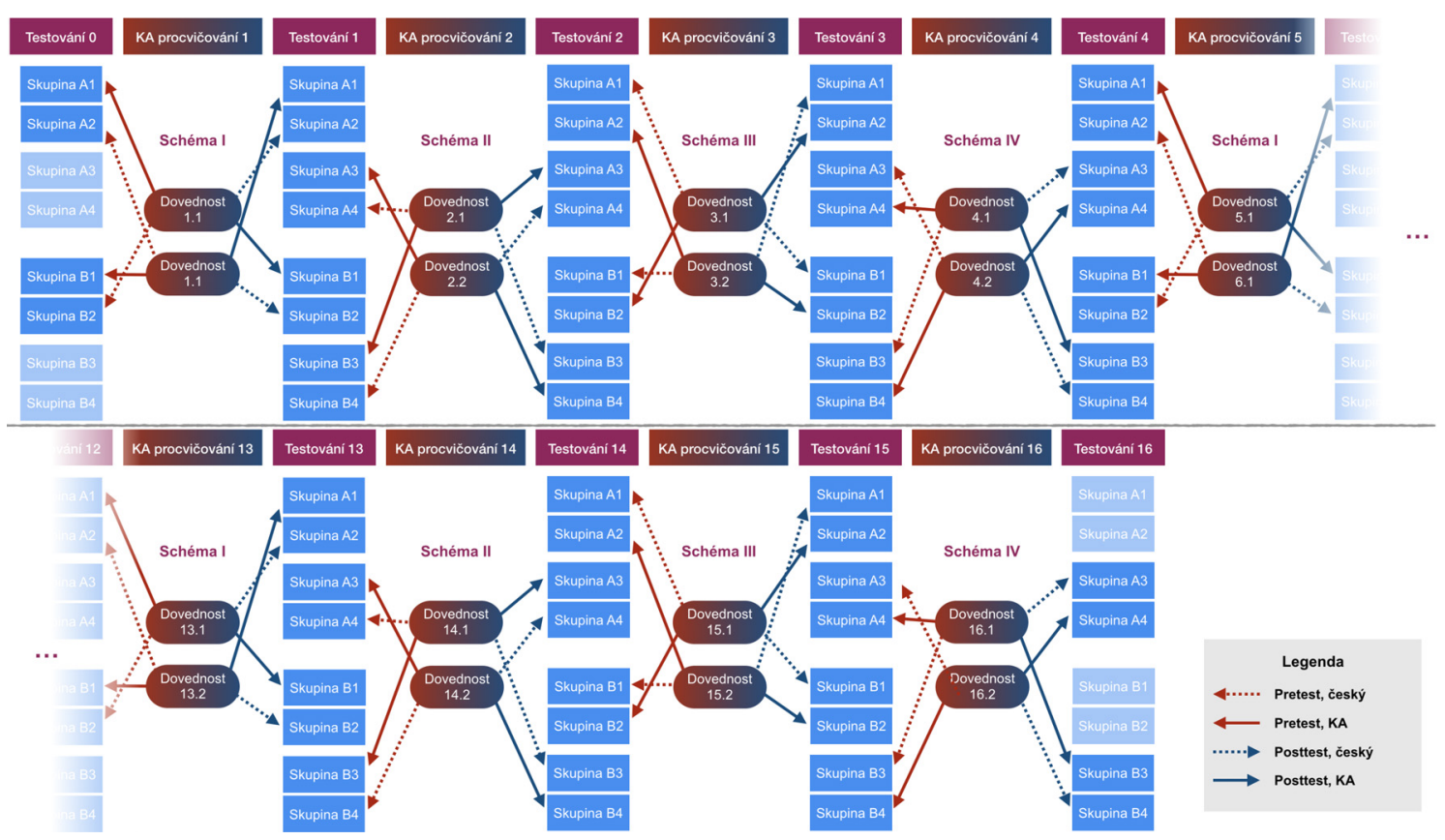

Obr. 6: Rozvrh testování žáků ve studii ve školním roce 2016/2017 
příprava testů byla jednodušší, nebot se jednalo přímo o úlohy, které studenti procvičovali na KA.

Například při testování 3 byla skupina A1 posttestována v českém kontextu na znalost 3.2; skupina A2 byla posttestována v kontextu Khan Academy na znalost 3.1; skupina A3 byla pretestována $\mathrm{v}$ českém kontextu na znalost 4.2 atd. Vzhledem $\mathrm{k}$ dvojnásobnému počtu různých testových variant byla každá skupina v jiné situaci a bylo třeba provést celkem 16 kol testování, abychom získali dostatek dat.

$\mathrm{V}$ případě obou studií probíhaly pretesty, domácí procvičování a posttesty až v době, kdy byla daná látka ve škole probrána. Po pretestech jsme se již snažili dané látce ve škole nevěnovat, abychom tak v co největší míře posttesem zjištovali pouze přínos procvičování na KA. V případě obou studií obsahoval každý test vždy jednu testovou úlohu zaměřenou na zkoumanou znalost.

$\mathrm{V}$ průběhu obou studií byli žáci známkováni za plnění zadaných cvičení. Do známky jsme zahrnuli nejen nejlepší dosažené výsledky žáka ve cvičeních, ale i úsilí, které domácímu úkolu věnoval, tedy i žák, který nesplnil všechna zadaná cvičení na $100 \%$, mohl dostat jedničku, pokud se snažil cvičení opravit a věnoval úkolu nadprůměrné množství času. Abychom dále zvýšili motivaci žáků k pečlivému řešení testových úloh ve škole, měli žáci možnost získat za správné řešení úlohy známku z matematiky.

V souladu s předchozími studiemi (Vančura, 2016; Murphy, 2014) se žáci na KA neučili nové koncepty a postupy, ale procvičovali znalosti dř́ve probrané ve škole.

\subsection{NÁVRH TESTOVÝCH ÚLOH}

Obsahem matematiky ve školním roce 2016/2017 ve třetím ročníku byla stereometrie, analytická geometrie a komplexní čísla. Vzhledem k tomu, že téma stereometrie není na Khan Academy dostatečně zpracováno, pracovala první studie s tématy analytické geometrie a komplexních čísel. Tato studie řešila výzkumnou otázku i), neboli přenos znalostí získaných v prostředí KA do českého, školního kontextu. Tomu odpovídal i návrh testových úloh. Žáci testovaní v kontextu KA řešili úlohu v podobě screenshotu cvičení z KA (viz obr. 7), jednalo se o cvičení, která byla zadaná v rámci domácího úkolu. Žáci testovaní v českém kontextu řešili analogickou úlohu přeloženou do českého jazyka bez grafiky KA (viz obr. 8).

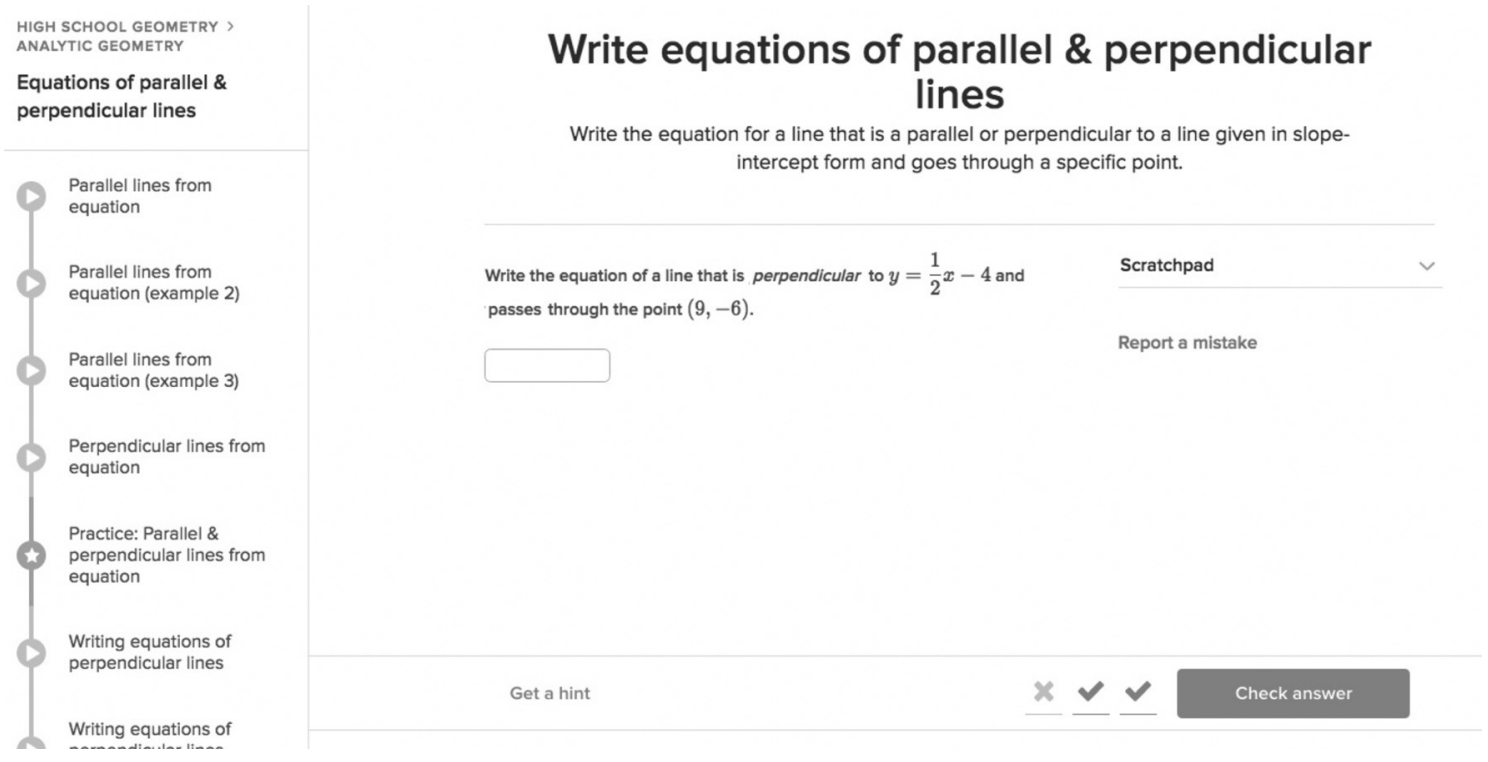

Obr. 7: Screenshot úlohy na Khan Academy 


$$
\begin{aligned}
& \text { Je dána přímka } p: y=-\frac{1}{2} x+2 . \text { Napište rovnici přímky } q \text {, která je kolmá na přímku } \\
& p \text { a prochází bodem } Q=[5,-7] .
\end{aligned}
$$

Obr. 8: Analogická úloha v českém kontextu

Při každém testování řešili žáci jednu úlohu, která byla obsahem bud’ následného domácího úkolu v případě pretesti̊, nebo předchozího domácího úkolu v případě posttestů.

V následujícím školním roce 2017/2018 jsme se zabývali otázkou ii), tedy rozvojem konceptuální znalosti. Záměrně jsme se zaměřili pouze na dovednosti 2.b-II (ilustrovat na prŕkladech) a 5.a-III (kontrolovat) RBT, nebot' je lze spolehlivě a opakovaně testovat a také se dají velmi dobře navázat na úlohy z KA. Tématem hodin matematiky i naší druhé studie byly limity, derivace a integrály, které skýtají širokou škálu matematických konceptů a poskytly tak vhodnou půdu pro testování konceptuálních znalostí. Vždy jsme se snažili testové úlohy co nejvíce propojit s příslušnými cvičeními na KA tak, abychom v maximální míře testovali vždy pouze přínos procvičování z posledního domácího úkolu. Dále pro ilustraci uvádíme příklady cvičení z KA, které žáci řešili v rámci domácích úkolo̊, a také př́klady testových úloh, jež z těchto cvičení vycházejí.

Obr. 9: Screenshot úlohy z domácího úkolu na Khan Academy zaměřeném na

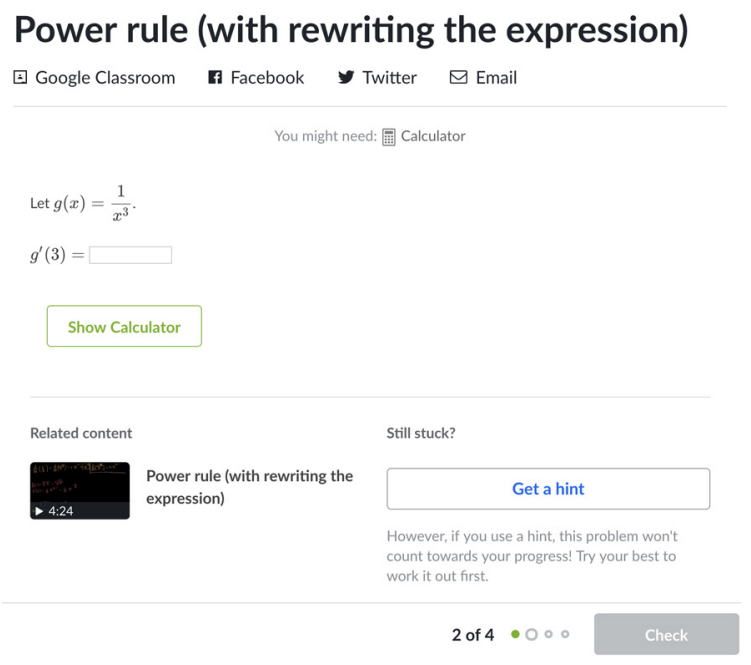
derivaci mocnin

Se cvičením na obr. 9 jsme spojili testovou úlohu na obr. 11, která testuje dovednost zhodnotit správnost předloženého postupu. Pro úplnost ještě obr. 10. ukazuje vzorový postup řešení z KA. Na cvičení na obr. 12 jsme navázali testovou úlohou na obr. 13, která overruje dovednost spadající do kategorie 2.b-II (vytvořit př́klad s danými vlastnostmi). Konečně přínos cvičení na obr. 14 a 15 jsme testovali pomocí úlohy na obr. 16, která také spadá do kategorie 2.b-II a ověřuje dovednost generovat vhodné protipř́klady.

\subsubsection{HODNOCENÍ TESTU゚}

V obou studiích obsahovaly testy vždy jednu úlohu, proto bylo možné je hodnotit jednoduše známkou na stupnici 1 až 5 následovně. Bezchybná řešení získala známku 1, řešení konceptuálně správná s numerickou chybou byla hodnocena 2 (obr. 17), známku 3 nebo 4 dostala řešení, která jsou částečně správně, ale obsahují konceptuální chyby (obr. 18). Známku 5 dostaly testy, které bud’ neobsahovaly 
We can first rewrite $g(x)$ as a negative power of $x$

Then, the derivative of $g$ can be found using the power rule:

$\frac{d}{d x}\left(x^{n}\right)=n \cdot x^{n-1}$

(Remember that this applies even when $n$ is negative.)

Once we have $g^{\prime}(x)$, we can plug $x=3$ into it to find $g^{\prime}(3)$.

Rewriting the fraction as a negative power

$g(x)=\frac{1}{x^{3}}=x^{-3}$

Differentiating using the power rule

$$
\begin{aligned}
& g^{\prime}(x) \\
= & \frac{d}{d x}\left(x^{-3}\right) \\
= & -3 x^{-3-1} \quad \text { The power rule } \\
= & -3 x^{-4}
\end{aligned}
$$

4/5 Evaluating $g^{\prime}(x)$

$$
\text { So we found that } g^{\prime}(x)=-3 x^{-4} \text {, which can also be written as }-\frac{3}{x^{4}} \text {. }
$$$$
\text { Now let's plug } x=3 \text { : }
$$$$
-\frac{3}{(3)^{4}}=-\frac{3}{81}
$$$$
=-\frac{1}{27}
$$

Obr. 10: Vzorový postup řešení úlohy na Khan Academy z obr. 9

$$
5 / 5 \text { In conclusion, } g^{\prime}(3)=-\frac{1}{27} \text {. }
$$

Obr. 11: Testová úloha zaměřená na dovednost 5.a-III (kontrolovat) Bloomovy taxonomie

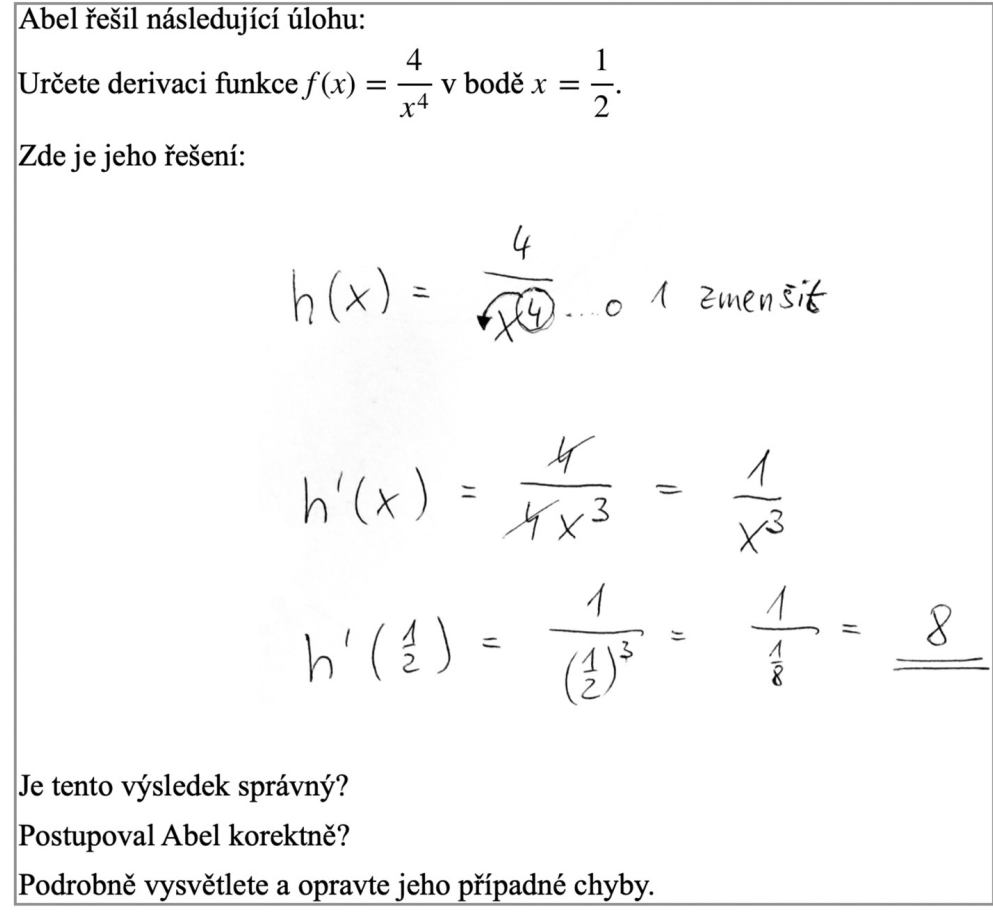




\section{Concavity intro}

Obr. 12: Screenshot Function $g$ is graphed. cvičení na Khan Academy zaměřeném na geometrický význam derivací

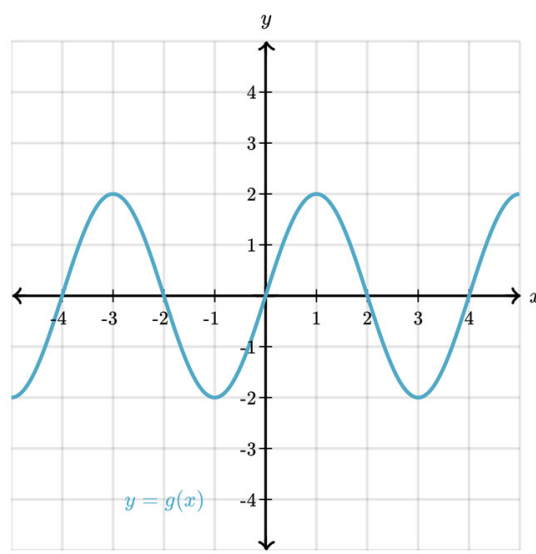

Select all the intervals where $g^{\prime}(x)>0$ and $g^{\prime \prime}(x)<0$.

Choose all answers that apply:

(A) $-4<x<-3$

(B) $0<x<1$

(C) $4<x<4.5$

(D) None of the above

Načrtněte graf libovolné funkce $f$ tak, aby zároveň platilo:
- $f^{\prime}(x)>0, f^{\prime \prime}(x)>0$ na intervalu $x \in(-4 ;-2)$
- $f^{\prime}(x)>0, f^{\prime \prime}(x)<0$ na intervalu $x \in(-2 ; 0)$
- $\quad f^{\prime}(x)<0, f^{\prime \prime}(x)<0$ na intervalu $x \in(0 ; 2)$
- $\quad f^{\prime}(x)>0, f^{\prime \prime}(x)>0$ na intervalu $x \in(2 ; 4)$

Obr. 13: Testová úloha zaměřená na dovednost 2.b-II (ilustrovat na př́íkladech)

Bloomovy taxonomie

\section{Relative maxima and minima}

$\square$ Google Classroom If Facebook $\checkmark$ Twitter $\square$ Email

Obr. 14: Screenshot cvičení na Khan Academy zaměřeném na hledání lokálních extrémů v grafu

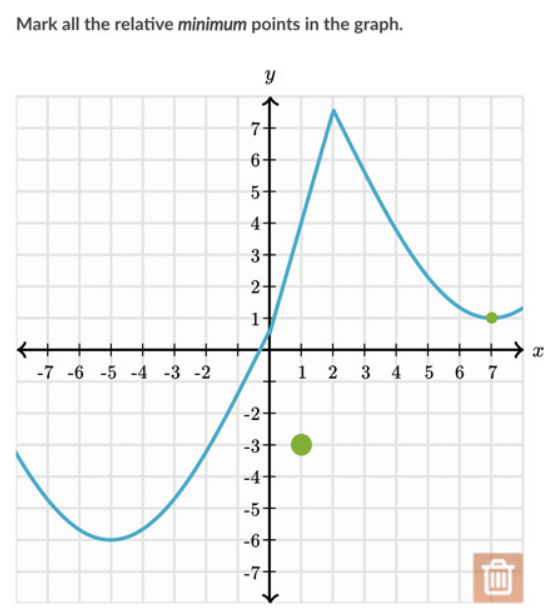




\section{Derivative as slope of curve}

@ Google Classroom If Facebook

Obr. 15: Screenshot cvičení na Khan

Academy

zaměřeném

geometrický význam derivace

Estimate $f^{\prime}(5)$

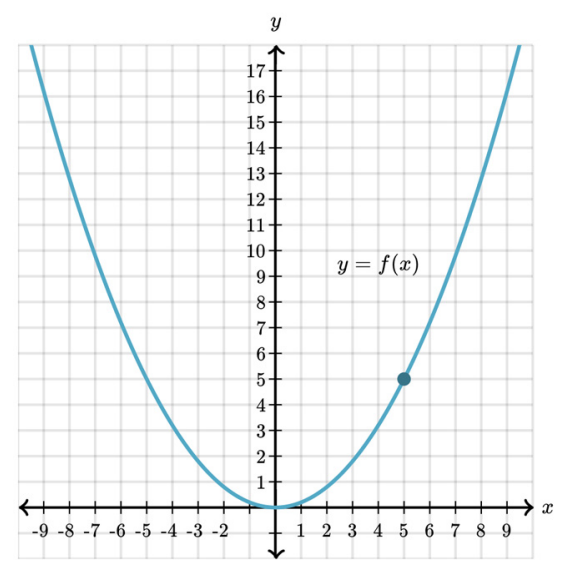

Choose 1 answer:

(A) 0.1

(B) 2

(C) -2

(D) -0.1

(E) 0

Standa si myslí, že pokud má funkce v nějakém bodě nulovou derivací,
musí v něm mít lokální maximum nebo minimum.
Uved'te vhodný příklad, který tuto mylnou domněnku vyvrátí.

Obr. 16: Testová úloha zaměřená na dovednost 2.b-II (ilustrovat na př́kladech) Bloomovy taxonomie
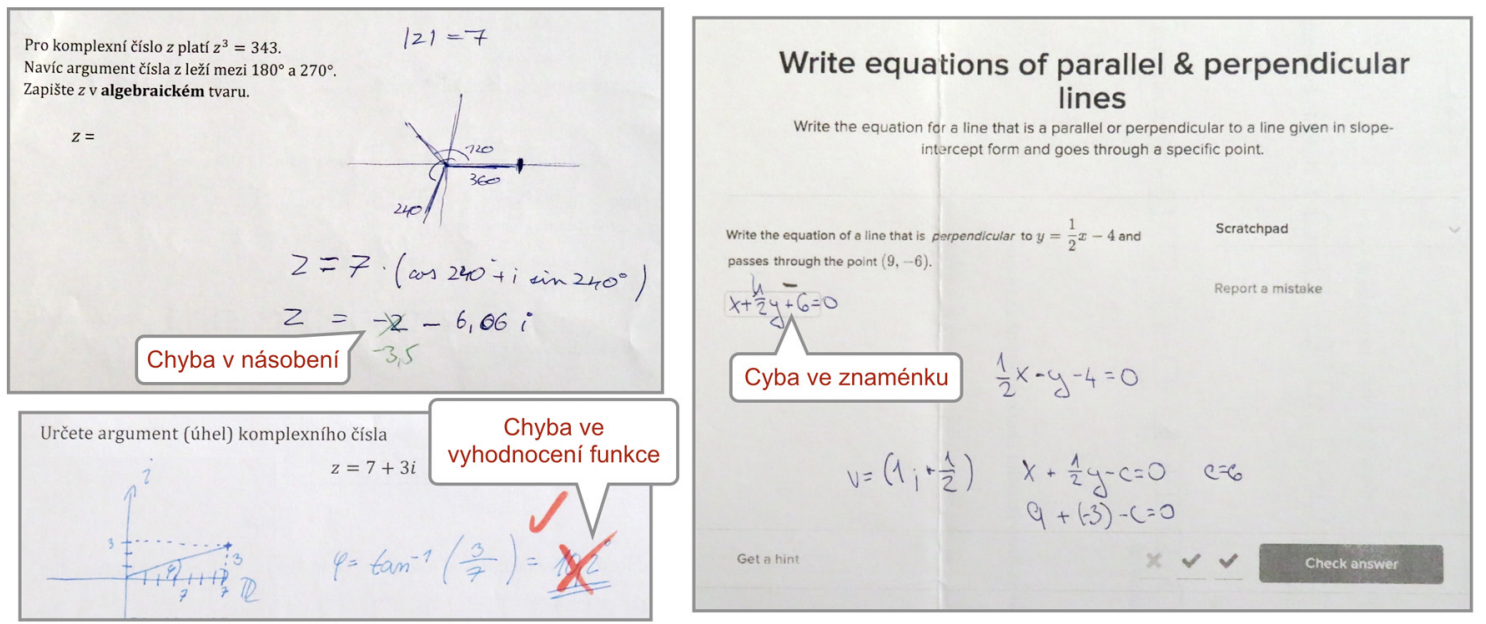

Obr. 17: Testy hodnocené známkou 2
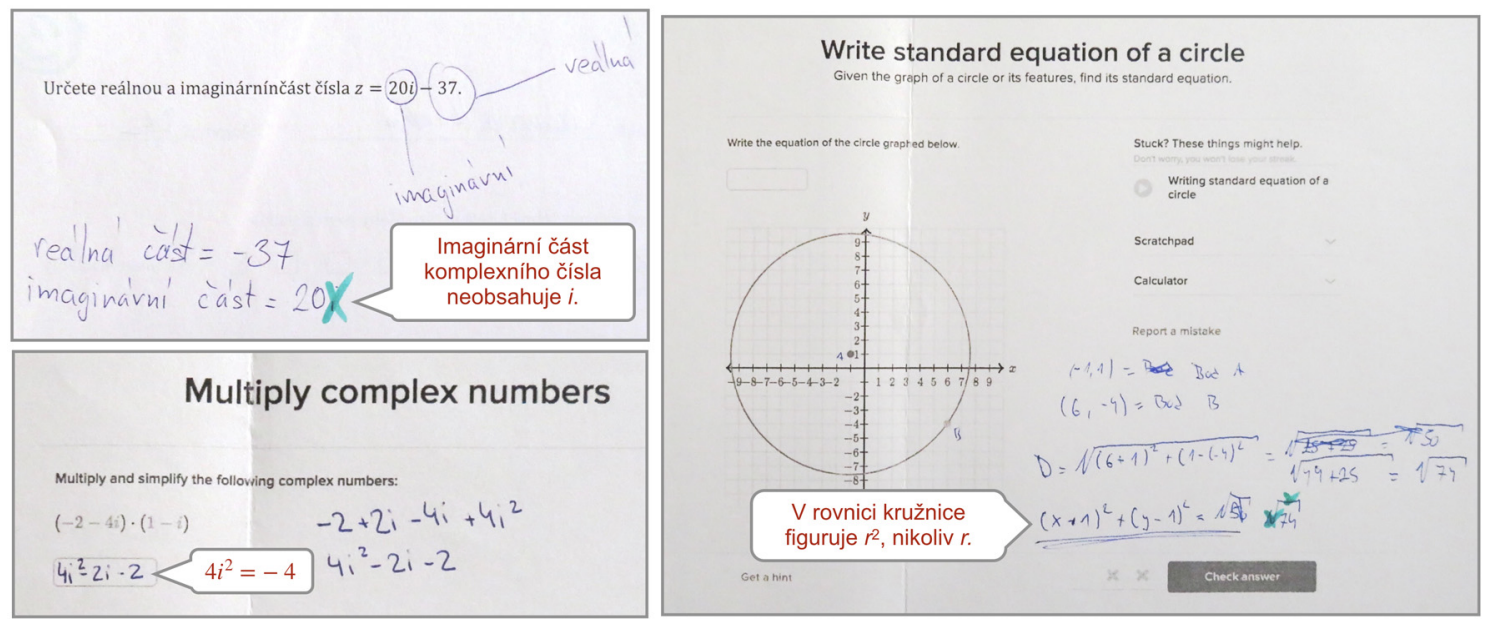

Obr. 18: Testy hodnocené známkou 3 nebo 4 

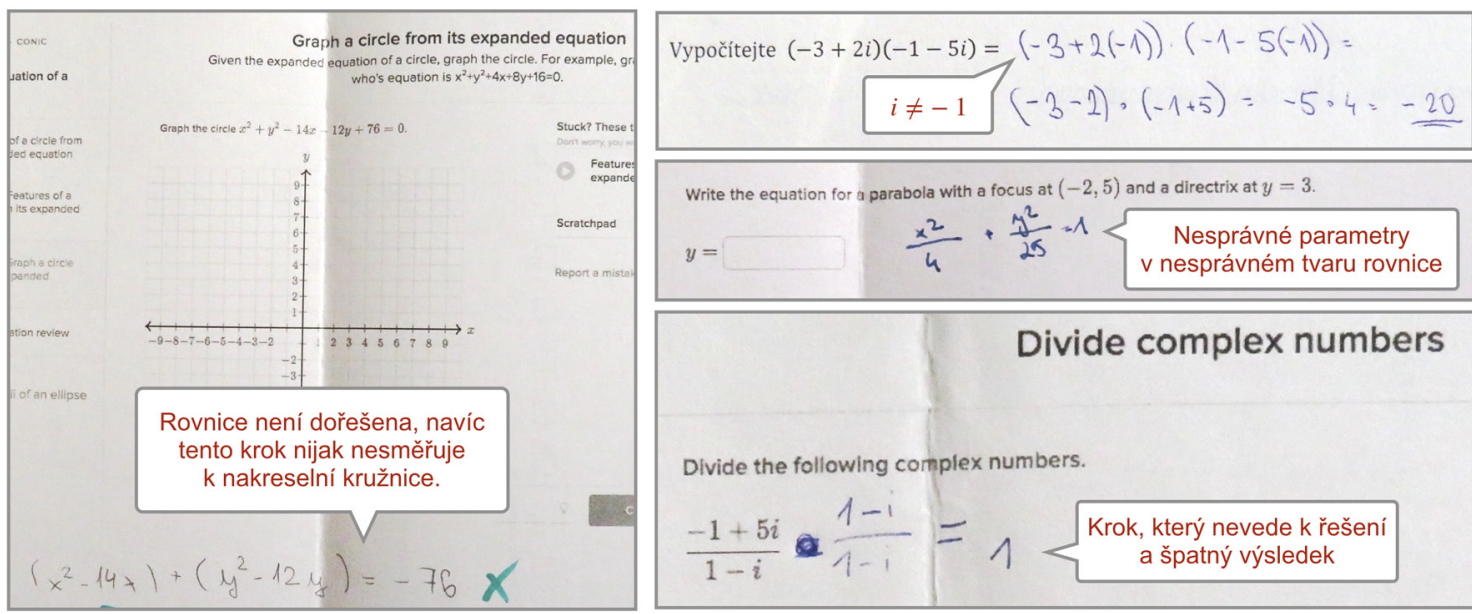

Obr. 19: Testy hodnocené známkou 5

žádné řešení, nebo bylo řešení konceptuálně zcela chybné (obr. 19). V př́ípadě nejistoty ohledně hodnocení testu vždy proběhla porada s dalším učitelem matematiky na témže gymnáziu. Díky tomu, že každý test obsahoval jen jednu úlohu a žáci měli na její řešení dostatek času, byla drtivá většina testů $(89,75 \%$ ) hodnocena známkou 1 nebo 5.

\subsection{2 ŽÁKOVSKÉ DOTAZNÍKY}

Obě studie také zkoumaly otázku iii) Jak přínosné je procvičování na Khan Academy dle vnímání žáků z hlediska jejich znalostí? Proto jsme na konec každého testu zařadili jednoduchý dotazník s jednou otázkou, která se žáků ptala, kde získali znalosti potřebné pro řešení testové úlohy. Žáci odpovídali na pětibodové škále, kdy na jedné straně byla možnost „výhradně ve škole“ a na druhé straně možnost „výhradně na Khan Academy“. Z každého testu jsme tak kromě známky získali názor žáka na převažující zdroj jeho znalostí potřebných k řešení testové úlohy.

\subsection{ANALÝZA DAT}

Než jsme podrobili známky z testů datové analýze, odstranili jsme v každé studii samostatně data od žáků, kteří v průběhu studie splnili méně než $50 \%$ zadaných domácích úkolů na KA. V první studii z roku 2016/2017 nám tak z původních 604 zůstalo 510 známek. Ve druhé studii z roku 2017/2018 nám z původních 310 zbylo 248 známek.

Vzhledem k tomu, že máme vždy dvě množiny známek - před a po procvičení, mohl by být vhodným nástrojem další analýzy dvouvýběrový t-test. Bohužel ale jednotlivé známky nejsou vzájemně nezávislé, nebot jsme testovali stále stejnou skupinu 44 žáků. Proto jsme u každého žáka vypočítali tzv. skóre zlepšení a provedli běžný Studentův t-test následujícím způsobem.

Označme $X_{i}$ průměr známek $i$-tého žáka před procvičením a $Y_{i}$ průměr známek $i$-tého žáka po procvičení. Skóre zlepšení $i$-tého žáka definujeme jako $Z_{i}=Y_{i}-X_{i}$. Testujeme alternativní hypotézu, že průměrné skóre zlepšení všech žáků není nulové proti nulové hypotéze, že toto průměrné skóre nulové je. Vypočítáme testovou statistiku $T_{n}=\sqrt{n} \cdot \frac{Z_{n}-0}{S Z}$, kde $n=34$ je počet žáků, jejichž data zůstala ve vzorku po odstranění dat žáků, kteří nedostatečně plnili domácí úkoly (v obou studiích zbyl stejný počet žáků, i když to nebyli zcela titíž žáci), $Z_{n}$ označuje průměrné skóre 
zlepšení všech žáků a $S Z$ je výběrová směrodatná odchylka skórů zlepšení. Studentův t-test požaduje normalitu vzorku. Přestože původní známky mají výrazně bimodální rozdělení, kdy většina známek je 1 nebo 5 , skóre zlepšení již tímto nedostatkem netrpí, nebot se jedná o hodnoty vypočtené z průměrů známek každého žáka. Navíc je počet skórů vyšší než 30, což je obecně považováno za dostatečný počet pro zanedbání požadavku normality.

Použili jsme oboustranný Studentův t-test s hladinou spolehlivosti $\alpha=0,05$. Dále jsme vypočítali intervaly spolehlivosti pro lepší představu o hodnotě průměrných skórů zlepšení. Celkem jsme provedli tři testy. Dva testy pro data z první studie z roku 2016/2017, kdy jsme zvlášt testovali zlepšení v kontextu KA a v českém, školním kontextu, a jeden test pro data z druhé studie z roku 2017/2018. Dále jsme prověřili rozdíly mezi chlapci a dívkami a také mezi žáky s volitelnou hodinou matematiky navíc a ostatními žáky. Také jsme prověřili rozdíly v přínosu mezi úlohami overujujícími dovednost 2.b-II (ilustrovat na příkladech) a úlohami ověřujícími dovednost 5.a-III (kontrolovat) RBT.

Data ze žákovských dotazníků jsme analyzovali jednoduchým výpočtem průměrné hodnoty a vizualizací v podobě histogramu.

\section{VÝSLEDKY}

V prř́padě první studie z roku 2016/2017 byla nulová hypotéza zamítnuta v obou případech. Intervaly spolehlivosti (viz obr. 20 modré) ukazují, že v obou dvou případech došlo k významnému zlepšení jak ze statistického, tak z didaktického hlediska. Odpověd’ na výzkumnou otázku i) tak zní: „Ano, žáci z výzkumného vzorku přenesli procedurální znalosti získané procvičováním na KA do českého, školního kontextu v oblasti analytické geometrie a komplexních čísel." Žáci se v průměru o něco více zlepšili v kontextu KA, tento rozdíl ale není statisticky významný. Zatímco před procvičením převažovala $\mathrm{v}$ obou kontextech známka 5 , po procvičení dosahovala většina žáků známky 1 . Nicméně i po procvičení bylo $18 \%$ testů hodnoceno známkou 5, těchto $18 \%$ není tvořeno občasným selháním např́č výzkumnou skupinou, ale jde spíše o několik žáků, kteří ani po procvičení nedosáhnou výrazného zlepšení (Vančura, 2018a).

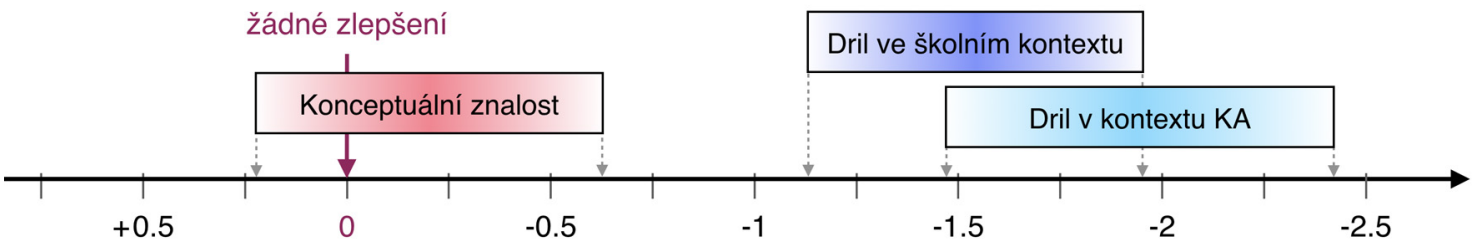

Obr. 20: Intervaly spolehlivosti pro průměrné skóry zlepšení

Naopak v případě druhé studie z roku 2017/2018, zabývající se výzkumnou otázkou ii) (rozvojem konceptuální znalosti), nebyla nulová hypotéza zamítnuta. Vidíme (obr. 20 červený), že interval spolehlivosti je vychýlen mírně doprava, ale nejedná se o statisticky významné zlepšení. Průměrné zlepšení je $Z_{n}=-0,20$, hranice intervalu spolehlivosti jsou $+0,23$ a $-0,64$. Můžeme tedy konstatovat, že procvičování na KA v oblasti diferenciálního a integrálního počtu významně nerozvíjí ani dovednost kontrolovat předložený postup, ani dovednost ilustrovat dané koncepty na vhodných př́kladech či protipř́ikladech. Jednou z možných příčin malého zlepšení by mohly 
být dobré výsledky již v pretestech, což ale nebyl tento případ. Průměrná známka z pretestu byla 3,89 a z posttestu 3,69 na stupnici od 1 do 5 .

Podívejme se na poslední výzkumnou otázku iii) - Jak přínosné je procvičování na Khan Academy dle vnímání žáků? Ukázalo se, že žáci vnímali přínos KA ve shodě s výsledky testi̊. Obr. 21 a 22 ukazují rozdělení odpovědí žáků na otázku, kde získali potřebné znalosti u obou studií. Vidíme, že v případě první studie z roku 2016/2017 došlo mezi pretestem a posttestem k výraznému posunu ve prospěch $\mathrm{KA}$, kdy před procvičením $55 \%$ žáků tvrdilo, že potřebné znalosti získali výhradně ve škole, zatímco po procvičení tvrdilo $45 \%$ žáků, že potřebné znalosti získali výhradně na KA. Naopak v př́padě druhé studie z roku 2017/2018 již není rozdíl tak markantní a i po procvičení žáci považují školu za dominantní zdroj potřebných znalostí.

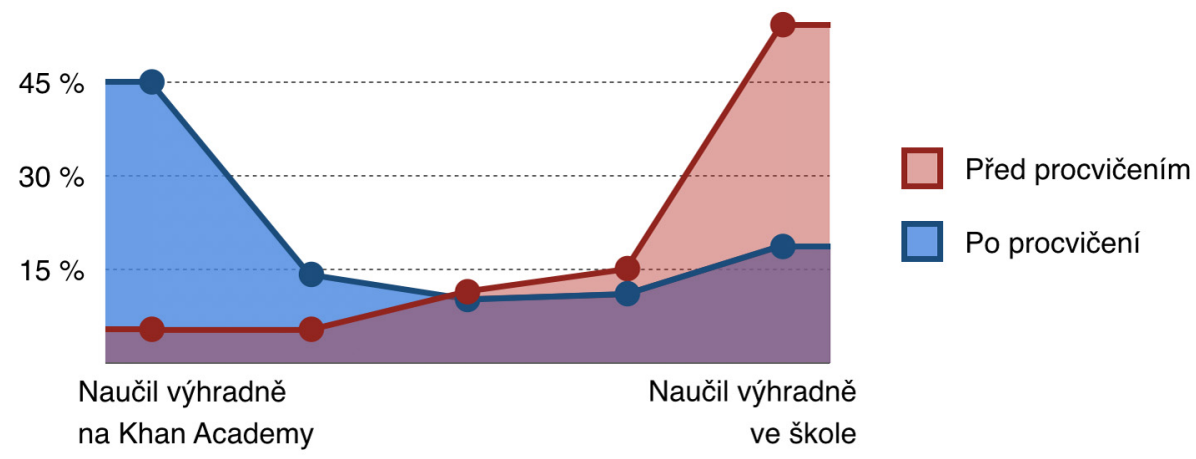

Obr. 21: Rozdělení odpovědí žáků na otázku, kde získali potřebné znalosti, v roce $2016 / 2017$

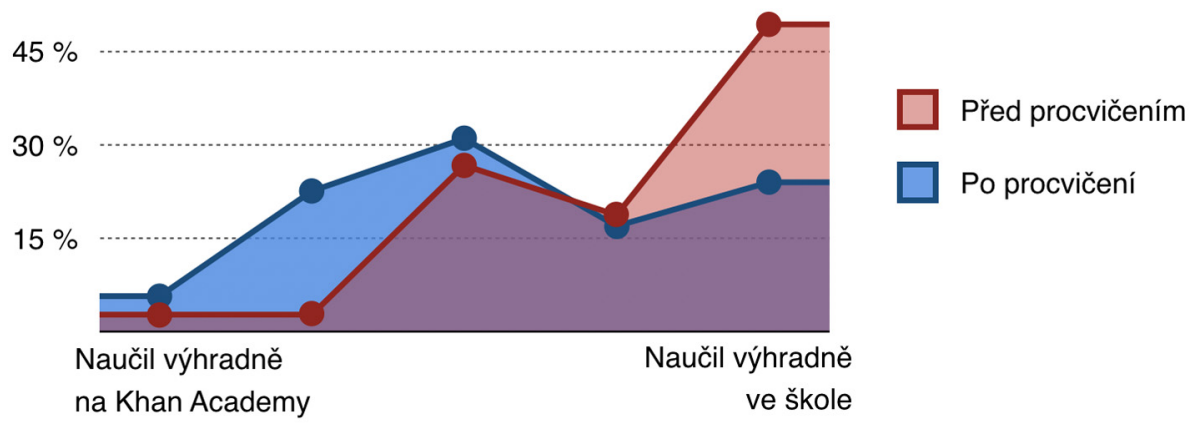

Obr. 22: Rozdělení odpovědí žáků na otázku, kde získali potřebné znalosti, v roce $2017 / 2018$

Při zkoumání rozdílů mezi chlapci a dívkami ani mezi žáky s volitelnou hodinou matematiky navíc a ostatními žáky jsme neodhalili statisticky významné rozdíly. Stejně tak jsme nezaznamenali rozdíl $\mathrm{v}$ úspěšnosti mezi úlohami zaměřenými na dovednost 2.b-II a úlohami zaměřenými na dovednost 5.a-III RBT.

\section{DisKuZE}

Z výsledků první studie z roku 2016/2017 vyplývá, že žáci dokáží provést nacvičené procedurální znalosti nejen v prostředí, ve kterém je získali, ale dokáží je i přenést do analogických úloh v českém, školním kontextu. Žáci jsou svým vnímáním ve shodě s empirickými výsledky testů, kdy většina žáků považuje KA za hlavní zdroj svých znalostí, které byly třeba pro řešení testů. Neplatí to ale plošně pro všechny žáky, ani pro všechna cvičení na KA. 
Někteří žáci byli schopni vyřešit po procvičení úlohy v kontextu KA, ale opakovaně nebyli schopni, ani po procvičení, vyřešit testové úlohy v českém kontextu (Vančura, 2018a). Jednou z prř́čin by mohla být jazyková bariéra těchto žáků, která má vliv na postoje ke KA (Vančura, 2017), to se ale nepotvrdilo. Mezi žáky, kteří nebyli schopni procvičenou znalost přenést do českého kontextu, byli jak žáci s jistou jazykovou bariérou, tak žáci bez ní. Bohužel se celkem jednalo o jednotky žáků a je tedy možné, že při rozsáhlejší studii by se vliv jazykové bariéry projevil. Naopak někteř́ žáci uměli úlohy řešit již v pretestech a neměli tak prostor pro zlepšení. Tito žáci pak často uváděli školu za hlavní zdroj svých znalostí, a to i po procvičení na KA. V dotaznících u posttestů 19 \% žáků označilo školu za výhradní zdroj svých znalostí. Těmto žákům by pravděpodobně více prospěl domácí úkol zaměřený na pokročilejší látku. Pro účely studie nebylo možné úkoly pro jednotlivé žáky diferencovat, nicméně KA toto umožňuje.

Zmiňme také, že na KA najdeme cvičení, u kterých většina žáků má problém s přenosem do českého školního kontextu. Příklad takového cvičení vidíme na obr. 23. Jedná se zpravidla o velmi mechanická cvičení, kde žák nemusí rozumět souvisejícím konceptům, ale stačí opakovat jednoduchou symbolickou operaci (Vančura, 2018a). Zde např́iklad stačí smazat minus pod odmocninou a před odmocninu napsat i, což lze provádět bez jakéhokoliv porozumění symbolu i. Cvičení bychom proto měli vybírat pečlivě, abychom se vyhnuli př́liš mechanickým cvičením, které je možno splnit bez základního pochopení procvičované látky.

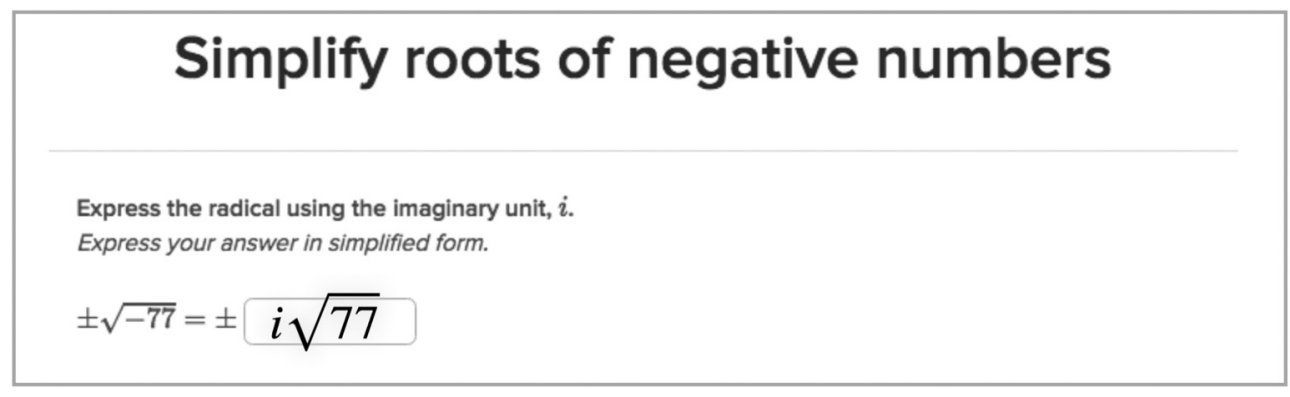

Obr. 23: Khan Academy cvičení zaměřené na výpočet komplexních odmocnin

Výsledky druhé studie z roku 2017/2018 naopak neukazují na velký přínos procvičování na KA. Cvičení na KA jsou v souladu s výsledky výzkumů v oblasti procvičování, žáci dostávají okamžitou zpětnou vazbu, mají k dispozici výuková videa a musejí cvičení opakovat, dokud nedosáhnou úspěšnosti alespoň 70 \%. Přesto překvapivě z výsledků studie vyplývá, že procvičování na KA nezlepšuje (alespoň ne statisticky významně) vybrané, vyšší kognitivní dovednosti žáků. RBT zde nabízí vysvětlení. Naprostá většina cvičení v kapitole věnované derivacím a integrálům spadá do kategorie 3.a (provádět) RBT. Jedná se o cvičení, kde žák provádí danou proceduru známým zpo̊sobem na známých typech příkladů, například řeší kvadratické rovnice pomocí vzorce a dochází pouze ke změně parametrů stejné rovnice. Původní verze (Bloom, 1956) byla postavena taxonomicky, kdy ke zvládnutí vyšších dovedností je nezbytné zvládnutí dovedností z předchozích úrovní. Naše studie ukazuje, že se nejedná v pravém slova smyslu o taxonomii, nebot žáci většinou dosáhli úrovně 3.a, aniž by se jim zlepšili dovednosti na úrovni 2.b. V novější verzi RBT (Anderson \& Krathwohl, 2001) již autoři uvádějí, že mezi jednotlivými úrovněmi neexistuje jasná hierarchie, takže je možné zvládnout dovednosti na úrovni 3 bez zvládnutí dovedností na úrovni 2. Naše studie ukazuje, že prosté procvičování úloh nemusí mít vliv ani na úroveň 2 (porozumění), ale ani na schopnost kont- 
rolovat správnost předloženého postupu. Žáci jsou, stejně jako v předchozí studii, svým vnímáním ve shodě s empirickými výsledky testů, kdy většina žáků tentokrát nepovažuje KA za hlavní zdroj svých znalostí ani po procvičování.

Ve srovnání s dalšími studiemi se jedná o poměrně extrémní výsledek. Procedurální a konceptuální znalost bývá často propojena, ale ne vždy se jedná o symetrický vztah (Rittle-Johnson et al., 2015), existují studie, kde konceptuálních znalostí má větší přínos pro procedurální znalosti než naopak (Hecht \& Vagi, 2010). Většího přínosu pro konceptuální znalost dosahuje takové vyučování zaměřené na procedurální znalost, které odhaluje související matematické koncepty např́iklad tím, že vybízí žáky k zobecňování prováděných procedur (Rittle-Johnson \& Schneider, 2016).

Projděme ještě faktory, které mohly ovlivnit výsledky druhé studie z roku 2017/2018. Za prvé - žáci mohli ztratit získané znalosti v čase mezi procvičením na KA a testováním ve škole. Většina žáků plnila zadaná cvičení o víkendu a byli testování hned v pondělí, není proto pravděpodobné, že by o získané znalosti zcela přišli, navíc v předchozí studii z roku 2016/2017 se tento efekt výrazně neprojevil. Za druhé - porozumění matematickým konceptům není izolovaná znalost a je možné, že žáci nabývali lepšího porozumění postupně, což se neprojevilo při testování na týdenní bázi. Také tento faktor nepovažujeme za významný. Jednak jsme se snažili vytvářet testové úlohy úzce zaměřené na jednotlivé koncepty (např. geometrický význam derivace) nebo algoritmy (derivace polynomů), které žáci v daném týdnu procvičovali. Jednak jsme tento faktor nezaznamenali v předchozí studii z roku 2016/2017, kde jsme pracovali s obdobnou metodikou rozvrhu testování a se stejnými žáky. Za třetí - žáci mohli testovaným konceptům dobře rozumět již před procvičením, čímž by nezbyl prostor pro zlepšení. Tento faktor jsme již ale vyloučili v minulé kapitole. Před procvičením činila průměrná známka z testu 3,89, po procvičení pak 3,69 na stupnici od 1 do 5. Za čtvrté - mohl za žáky řešit domácí úkol někdo jiný. Tento postup by byl ale pro jiné řešitele časově stejně náročný, nebot každý žák dostává na KA v rámci stejného cvičení jiné, byt analogické úlohy. Není tedy možné jednoduše vyřešit spolužákův úkol opsáním svých výsledků. Tento faktor je dále marginalizován delším časovým rámcem studie. Navíc ani tento faktor se v předchozí studii neprojevil.

U nástrojů podobných KA, které jsou v souladu s výzkumy v oblasti procvičování a zpětné vazby (Attali, 2015; Clarina \& Koul, 2003), můžeme očekávat na znalosti žáků obdobný efekt, kdy žáci jsou schopni provádět nacvičené početní procedury v různých kontextech, ale nezískávají lepší porozumění matematickým konceptům. Zdaleka ne všechny digitální nástroje určené pro procvičování ale nabízejí vhodné prostředí.

\subsection{LIMITY VÝZKUMU}

Výsledky první studie z roku 2016/2017 zaměřené na přenos procedurálních znalostí jsou sice statisticky významné, jednalo se ale o malou skupinu žáků z jednoho pražského gymnázia, proto není možné výsledky jednoduše zobecnit a bude třeba dalších výzkumů. Druhá studie z roku 2017/2018 nedospěla ke statisticky významným výsledkům a má stejné limity jako první studie, nicméně může sloužit jako varování proti př́liš zbrklému a rozsáhlému zavádění technologií, které nejsou podepřeny robustním výzkumem, do výuky matematiky. Rozdíl mezi výsledky studií mohl být také způsoben rozdílnými matematickými tématy, kdy oblast diferenciálního a integrálního počtu mohla být pro žáky výrazně náročnější než oblast analytické geometrie a komplexních čísel. 


\section{ZÁvĚR}

Domácí úkoly jsou běžnou součástí výuky matematiky, ale zadávání, kontrolování a hodnocení úkolů v souladu s výsledky výzkumů je v tradiční třídě z časových důvodů prakticky nemožné. První studie z roku 2016/2017 ukazuje, že KA umožní učiteli zadávat a kontrolovat plnění úkolů v tématu analytické geometrie a komplexních čísel, které významně zlepšují procedurální znalosti žáků. Podobný efekt můžeme očekávat $\mathrm{u}$ dalších nástrojů, které jsou v souladu s výsledky výzkumů v oblasti procvičování a zpětné vazby. Druhá studie z roku 2017/2018 nepopírá přínos KA jako nástroje drilu, ale ukazuje, že KA není vhodným nástrojem k rozvoji konceptuálních znalostí v oblasti diferenciálního a integrálního počtu. Tento výsledek není př́liš překvapivý, nebot drtivá většina cvičení na KA je zaměřena na úroveň 3.a RBT, provedení dané početní procedury ve známém kontextu. Pokud bychom chtěli rozvíjet jiné úrovně dovedností, měli bychom použít jiné typy úloh specificky zaměřené na kýžené dovednosti. RBT nabízí řadu typů vhodných úloh a cvičení pro každou kategorii dovedností.

V poslední době se objevují digitální nástroje a studie pracující s komplexnějšími a méně rutinními úlohami. Mezi odborníky převažuje názor, že rozvoj dobrého porozumění a hlubokého učení vyžaduje vždy nové a neobvyklé prostředí a kontext. Vyvolání cíleného kognitivního konfliktu pomocí nestandardních úloh je přínosný přístup k návrhu testů; žáci by neměli dostávat standardizované otázky (Bokhove \& Drijvers, 2012). Úlohy, kde žáci v digitálním prostředí vytvářejí předpovědi pomocí vhodných matematických modelů, mohou rozvíjet jejich schopnost uvažování a argumentace (Brunström \& Fahlgren, 2015). Přínos digitálních technologií spočívá mimo jiné ve schopnosti zobrazovat matematické koncepty efektivně a podnětně. Proto při snaze podpořit žákovské porozumění můžeme začít navrhovat úlohy a učební procesy s využitím digitálních technologií tak, abychom propojovali výpočetní techniky s matematickým porozuměním (Jupri, Drijvers \& van den Heuvel-Panhuizen, 2016).

Novější digitální nástroje, které nabízejí komplexnější úlohy (např. Desmos, 2019), zatím ale nepokrývají tolik oblastí jako KA, nenabízejí obdobnou podporu pro učitele a uživatelskou přívětivost jako KA a také nejsou empiricky prozkoumány jejich prŕnosy pro znalosti a dovednosti žáků.

\section{PODĚKOVÁNí}

Rád bych poděkoval doc. RNDr. Jarmile Robové za inspirativní vedení a věcné a užitečné připomínky. Dále bych rád poděkoval 44 žákům z gymnázia Př́potoční, kteří se účastnili obou studií, a jejichž učení tak mohlo být omezeno ve jménu objektivity a srovnatelnosti výzkumu.

Tento výstup byl podpořen projektem PROGRES Q17 Příprava učitele a učitelská profese v kontextu vědy a výzkumu a projektem SVV 2017 č. 260454.

\section{LITERATURA}

Alcock, L., Ansari, D., Batchelor, S., Bisson, M., Smedt, B. D., Gilmore, C. \& Weber, K. (2016). Challenges in mathematical cognition: A collaboratively-derived research agenda. Journal of Numerical Cognition, 2(1), 20-41. https://doi.org/10.5964/jnc.v2i1.10

Anderson, L. W. \& Krathwohl, D. R. (2001). A taxonomy for learning, teaching, and assessing: A revision of Bloom's taxonomy of educational objectives. New York: Longman. 
Attali, Y. (2015). Effects of multiple-try feedback and question type during mathematics problem solving on performance in similar problems. Computers \& Education, 86, 260-267. https://doi.org/10.1016/j.compedu.2015.08.011

Bempechat, J., Li, J., Neier, S. M., Gillis, C. A. \& Holloway, S. D. (2011). The homework experience: Perceptions of low-income youth. Journal of Advanced Academics, 22(2), 250-278. https://doi.org/10.1177/1932202X1102200204

Berthold, K. \& Renkl, A. (2009). Instructional aids to support a conceptual understanding of multiple representations. Journal of Educational Psychology, 101(1), 70-87. https://doi.org/10.1037/a0013247

Bloom, B.S. (1956). Taxonomy of educational objectives: The classification of educational goals. New York: Longmans, Green. https://doi.org/10.1177/001316445601600310

Bokhove, C. \& Drijvers, P. (2012). Effects of a digital intervention on the development of algebraic expertise. Computers \& Education, 58(1), 197-208.

https://doi.org/10.1016/j.compedu.2011.08.010

Brunström, M. \& Fahlgren, M. (2015). Designing prediction tasks in a mathematics software environment. International Journal for Technology in Mathematics Education, $22(1), 3-18$.

Cambridge Assessment. (2019). United Kingdom. Dostupné

z https://www.cambridgeenglish.org/exams-and-tests/

Clarina, R. \& Koul, R. (2003). Multiple-try feedback and higher-order learning outcomes. International Journal of Instructional Media, 32(3), 239-245.

Crompton, H., Burke, D. \& Lin, Y. C. (2019). Mobile learning and student cognition: A systematic review of PK-12 research using Bloom's Taxonomy. British Journal of Educational Technology, 50(2), 684-701. https://doi.org/10.1111/bjet.12674

Desmos. (2019). Dostupné z https://teacher.desmos.com [cit. 8. 5. 2019]

Dettmers, S., Trautwein, U., Lüdtke, O., Kunter, M. \& Baumert, J. (2010). Homework works if homework quality is high: Using multilevel modeling to predict the development of achievement in mathematics. Journal of Educational Psychology, 102(2), 467-482. https://doi.org/10.1037/a0018453

Dixon, J. A., Deets, J.K. \& Bangert, A. (2001). The representations of the arithmetic operations include functional relationships. Memory and Cognition, 29(3), 462-477.

Fan, H., Xu, J., Cai, Z., He, J. \& Fan, X. (2017). Homework and students ${ }^{6}$ achievement in math and science: A 30-year meta-analysis, 1986-2015. Educational Research Review, 20, 35-54. https://doi.org/10.1016/j.edurev.2016.11.003

Haapasalo, L. \& Kadijevich, D. (2000). Two types of mathematical knowledge and their relation. Journal für Mathematik-Didaktik, 21(2), 139-157.

https://doi.org/10.1007/BF03338914

Hecht, S. A. \& Vagi, K. J. (2010). Sources of group and individual differences in emerging fraction skills. Journal of Educational Psychology, 102(4), 843-859.

https://doi.org/10.1037/a0019824

Jupri, A., Drijvers, P. \& van den Heuvel-Panhuizen, M. (2016). An instrumentation theory view on students' use of an applet for algebraic substitution. International Journal for Technology in Mathematics Education, 23(2), 63-80.

Kamii, C. \& Dominick, A. (1997). To teach or not to teach algorithms. The Journal of Mathematical Behavior, 16(1), 51-61. https://doi.org/10.1016/S0732-3123(97)90007-9 
Kadijevich, Dj. \& Marinkovic, B. (2006). Challenging mathematics by „Archimedes“. The Teaching of Mathematics, 9(1), 31-39.

Khan Academy. (2018). Dostupné z http://www.khanacademy.org [cit. 7. 12. 2018]

Knuth, E. J., Stephens, A. C., McNeil, N. M. \& Alibali, M. W. (2006). Does understanding the equal sign matter? Evidence from solving equations. Journal for Research in Mathematics Education, 37(4), 297-312.

Lavigne, N. C. (2005). Mutually informative measures of knowledge: Concept maps plus problem sorts in statistics. Educational Assessment, 10(1), 39-71.

https://doi.org/10.1207/s15326977ea1001_3

Mueller, C. M. \& Dweck, C.S. (1998). Praise for intelligence can undermine children's motivation and performance. Journal of Personality and Social Psychology, 75(1), 33-52. https://doi.org/10.1037/0022-3514.75.1.33

Murphy, R., et al. (2014). Research on the use of Khan Academy in schools. Menlo Park, CA: SRI Education. Dostupné z https://www.sri.com/sites/default/files/publications/ 2014-03-07_implementation_briefing.pdf

Mustaffa, N., Ismail, Z., Said, M. N. H. M. \& Tasir, Z. (2017). A review on the development of algebraic thinking through technology. Advanced Science Letters, 23(4), 2951-2953. https://doi.org/10.1166/asl.2017.7615

Rittle-Johnson, B. (2006). Promoting transfer: effects of self-explanation and direct instruction. Child Development, 77(1), 1-15.

https://doi.org/10.1111/j.1467-8624.2006.00852.x

Rittle-Johnson, B. \& Schneider, M. (2016). Developing conceptual and procedural knowledge of mathematics. In The Oxford handbook of numerical cognition (pp. 1102-1118). Oxford, United Kingdom: Oxford University Press. https://doi.org/10.1093/oxfordhb/9780199642342.013.014

Rittle-Johnson, B., Schneider, M. \& Star, J. R. (2015). Not a one-way street: Bidirectional relations between procedural and conceptual knowledge of mathematics. Educational Psychology Review, 27(4), 587-597.

https://doi.org/10.1007/s10648-015-9302-x

Similar web. (2019). Dostupné z http://www.similarweb.com/website/khanacademy.org [cit. 8. 5. 2019]

Star, J. R. (2005). Reconceptualizing procedural knowledge. Journal for Research in Mathematics Education, 36(5), 404-411. https://doi.org/10.2307/30034943

Star, J. R. \& Rittle-Johnson, B. (2009). It pays to compare: an experimental study on computational estimation. Journal of Experimental Child Psychology, 102(2), 408-426. https://doi.org/10.1016/j.jecp.2008.11.004

Strandberg, M. (2013). Homework - is there a connection with classroom assessment? A review from Sweden. Educational Research, 55(4), 325-346.

https://doi.org/10.1080/00131881.2013.844936

Trautwein, U. \& Lüdtke, O. (2009). Predicting homework motivation and homework effort in six school subjects: The role of person and family characteristics, classroom factors, and school track. Learning and Instruction, 19(3), 243-258.

https://doi.org/10.1016/j.learninstruc.2008.05.001

Vančura, J. (2016). Využití Khan Academy pro výuku matematiky na střední škole. Setkání učitelů matematiky všech typů a stupňů škol 2016. Plzeň, Vydavatelský servis. 
Vančura, J. (2017). Research on the language barriers of students who use Khan

Academy as a mathematics homework platform. CERME 10 Proceedings (2660-2667). Dublin. Dostupné

z https://keynote.conference-services.net/resources/444/5118/pdf/CERME10_0195.pdf

Vančura, J. (2018a). Can students transfer their mathematical skills gained from their Khan Academy homework to other contexts? INTED 2018 Proceedings (2707-2714).

Valencia. https://doi.org/10.21125/inted.2018

Vančura, J. (2018b). Využití Khan Academy pro zadávání a hodnocení domácích úkolů. Matematika, fyzika, informatika, 28(3), 169-180.

Wilson, J. \& Rhodes, J. (2010). Student perspectives on homework. Education, 131(2), $351-358$.

Zákon č. 561/2004 Sb., o předškolním, základním, středním, vyšším odborném a jiném vzdělávání, školský zákon. (2004). Praha: Tiskárna Ministerstva vnitra.

JIŘÍ VANČURA, jivancura@gmail.com

Univerzita Karlova, Matematicko-fyzikální fakulta

Katedra didaktiky matematiky

Sokolovská 83, 18675 Praha 8, Česká republika 